Jens Toft

\title{
Westerns - Den genskrevne oprindelsesmyte
}

\begin{abstract}
"... one of the things the Western is always about is America rewriting and reinterpreting her own past, however honestly or dishonestly it may be done« (Philip French).
\end{abstract}

"Le Western est une mythologie sécularisée où une société tente de réfléchir ses contradictions sous couleur d'en retracer l'origine« (André Glucksmann).

Western-filmen som stabiliseret genre, som det kulturelt-samfundsmæssige massekommunikationsfænomen, vi kender i dag, bliver til omkring 1930 , som et produkt af en lang række forskellige faktorer, hvis historiske baggrund er forskellig, og som derfor ikke kan beskrives samlet. Tværtimod har de enkelte elementer hver deres forhistorie. Og i en vis forstand også deres autonome nutidshistorie uden for western-genren.

Det er dog ikke disse enkelt-elementer, jeg her vil beskæftige mig med, men med det kompleks, disse elementer tilsammen, på et givet tidspunkt, danner: western-filmen. Ikke desto mindre ønsker jeg her indledningsvis at understrege denne komplekse tilblivelseshistorie.

Der findes cow-boy-film før 1930, som for de flestes vedkommende blot er en af western-filmens mange forhistorier. Men blandt disse mange typer cow-boy-film udvikles én tendens, som lægger grundlaget for og kodificerer det værdisystem og den æstetik, der bliver den klassiske western's omkring 1930: William S. Hart. »William Hart gav westernfilmen den ophøjethed og moralske strenghed, som alle talefilmens western-helte senere har, fra Gary Cooper til Clark Gable. Ud af meget simple historier ... fremtvang Hart til sidst en kode« (Le Western, $\mathrm{p}$. 303).

Hvorfor er det da omkring 1930, western-filmen stabiliseres som det socio-kulturelle fænomen, vi kender i dag? Én forklaring finder man hos Peter Bächlin: Omkring 1930 er de økonomisk-tekniske betingelser til stede for masseproduktion og -distribution af tonefilm. Disse fordrer dog enorme kapitalinvesteringer og følgelig krav om tilsvarende stor profit: filmen bliver en storindustri med hvad deraf følger mht. organisering af arbejdsprocessen: rationalisering, afsætningsplanlægning $\mathrm{mm}$. 
Filmen lægges an på de store populære genrer med mulighed for masseafsætning og for rationalisering af selve produktionsprocessen.

Selv om dette kun er en af forklaringerne, er den dog i sig selv af temmelig kompleks karakter. Forudsætningerne er jo endda på dette niveau dobbelte: 1) den tekniske forudsætning (talefilmen, men den har jo været til stede siden 1890'erne, blot ikke i en sådan form, at det var økonomisk rentabelt at masseproducere den), 2) den økonomiske forudsætning, den amerikanske kapitalkoncentration: det var nødvendigt med kapitaler af en vis størrelse for overhovedet at muliggøre investeringer i det omfang, der her er tale om. Endelig en vis købedygtighed hos publikum: lønninger som tillader masserne at bruge penge på biografbilletter.

En anden forklaring, som hænger sammen med den forste, er af mere socialpsykologisk art: massernes behov, nødvendigheden af konsum af medieprodukter som instrument for tilvejebringelsen af den sammenhæng i tilværelsen, som ikke umiddelbart eksisterer for masserne i de højt industrialiserede kapitalistiske lande. Opsplitningen af tilværelsen $i$ arbejds- og fritids/familiesfære, »samfundsmæssiggørelsen « som sætter sig igennem bag individernes ryg gennem kapitalens totaliserende bevægelse. Heraf nødvendigheden af en »skin-syntese«.

I denne »skin-syntese« af virkeligheden indgår elementer af forskellig karakter og oprindelse: filmen som massemedium bliver et instrument, en »maskine«, som gennem et fiktivt forløb skal søge at holde sammen på og bringe en eller anden form for »acceptabel « »enhed « mellem massernes umiddelbare livssituation og de indlærte idealer, handlingsnormer osv., der for massernes parcellerede tilværelse netop ikke indgår $\mathrm{i}$ en umiddelbar realsyntese.

I denne sammenhæng bliver netop western-filmen central. Som den »oprindelsesmyte« den er. Selve den måde, den kapitalistiske produktionsmåde parcellerer tilværelsen på, desintegrerer massernes umiddelbare erfaringer vak fra den samfundsmæssige selvforståelse, som er nationens, og som har en høj grad af autenticitet i nationens tilblivelsesfa$s e$, i hvert fald tilsyneladende, men som bliver mere og mere åbenlyst falsk.

Fra en socialpsykologisk vinkel ser jeg western-filmens funktion som. den, gennem et fiktivt forløb, at re-integrere massernes umiddelbare erfaringer i den nationale selvforståelse. Derved bliver genren et krydsningspunkt mellem to whistorier«: den historie, hvor den nationale selvforståelse har sin oprindelse, og hvor den er autentisk, og den samtidshistorie, som er tilskuerens, og hvis umiddelbart registrerbare erfaringer, isoleret fra tilskuerens hverdag, skal flyttes til en anden tid, for dér at finde en »troværdig« løsning. Den bearbejdning af tilskuerens 
hverdagserfaring, som western-filmen foretager, kan derfor, med $\mathrm{Hol}$ zers udtryk, dækkende karakteriseres som »opbygning og nedbrydning af kognitive og emotionelle dissonanser «.

Denne funktion opfyldes ved hjælp af en række instrumenter, teknikker. André Bazin (1958) peger på de store Hollywoodgenrers sammenhæng med et bestemt filmisk ideolekt, som også eksisterer uden for disse genrer og med en delvist anden funktion. Mens Bernard Dort peger på western-filmens narrative strukturer og disses sammenhæng med karakteren af de erfaringer, der søges integreret i myten, og med vanskelighederne ved at foretage denne integration på en måde, der ikke ser bort fra alt for umiddelbare og påtrængende problemer og erfaringer.

I det følgende er det western-filmens social-psykologiske funktion, jeg vil koncentrere mig om og gøre til det strukturerende princip i fremstillingen, idet det er min opfattelse, at det er ud fra denne funktion, at western-filmens udvikling kan beskrives med størst præcision og først og fremmest med størst meningsfuldhed. Fra denne synsvinkel forekommer udviklingsmønstret nemlig ikke tilfældigt, som et resultat af tilfældige "modeluner" eller af enkelte geniale kunstneres personlige indsats.

Man må her skelne mellem genrens tilblivelse og dens videre $u d v i k$ ling. Mens en social-psykologisk fork laring langt fra er udtømmende mht. at beskrive genrens tilblivelse, er det min hypotese, at den meningsfuldt kan beskrive udviklingen. Det social-psykologiske "behov« for westerns kan siges at eksistere før og uafhængigt af western-filmens eksistens. Men hvad hjælper det, hvis de teknisk-økonomiske betingelser for at producere og distribuere sådanne film ikke er til stede. Disse betingelser skabes ikke af det social-psykologiske behov for disse film, men af forhold på et andet niveau, i teknikken og i økonomien. Western-filmerrs tilblivelse kan derfor beskrives som et "tilfældigt " historisk "møde « mellem 1) en teknisk og økonomisk udvikling, som har sin autonome udviklingslogik, 2) en i forvejen eksisterende delvist stabiliseret narratologisk og moralsk kode, som, blandt andre eksisterende - privilegeres og udvælges af 3) et masse-psykologisk behov, hvis historie skal søges i produktionsmådens fundamentale livsvilkår.

Men fra det øjeblik, hvor western-filmen er blevet til og har stabiliseret sig som genre, opstår en særlig "genre-logik«, som ikke er identisk med de første »logikker«, men må betragtes som en selvstændig logik, der ikke kan reduceres til de underliggende "logikker«: genrens udviklingslogik konstitueres gennem et bestemt »ordningsforhold» mellem de i den indgående »logikker«: social-psykologiske, narratologiske, æstetiske, tekniske, økonomiske osv., hvor det er de social-psykologiske behov, der overdeterminerer de øvrige »logikker«. 
Hvor den teknisk-økonomiske udvikling altså kan siges at være determinerende for western-filmens tilblivelse, på lige fod med de socialpsykologiske behov, filmæstetiske, narratologiske oa. traditioner, er forholdet et andet fra og med genrens eksistens. Fra da af er teknikken og film-økonomien noget der »er der«, og de ændringer, western-filmen har undergået siden starten, skyldes ikke tekniske og filmøkonomiske forhold. De tekniske ændringer, filmen har gennemgået siden ca. 1930 har ikke medfort fundamentale ændringer i western-filmen, omend de er blevet integreret $\mathbf{i}$ den i det omfang, dens social-psykologiske funktion har krævet det.

\section{Western-myten og historien}

I næsten al litteratur om western-film fremhæves to forhold: 1) genrens universalitet, der oftest knyttes til dens karakter af at være ren myte, noget oprindeligt og alment-menneskeligt, og 2) genrens "degenerering" efter 2. Verdenskrig, et forhold, der oftest knyttes til et påstået forræderi i forhold til oprindeligheden og myten.

Ved western-genrens universalitet forstås såvel dens forbløffende tidsmæssige livskraft - den opstod omtrent samtidig med filmen selv, og dens popularitet er usvækket den dag i dag - som dens geografiske ekspansion: westerns ses af millioner over hele kloden. Ikke så underligt, at man har følt sig fristet til at søge efter a-historiske, alment-menneskelige strukturer og problemstillinger i genren for at forklare dette forhold.

Problemet med sådanne forklaringer er primært, at de er idealistiske: menneskelige ideer og forestillinger løsrives fra deres sociale oprindelse og sammenhæng og tillægges selvstændig eksistens.

Et eksempel herpå findes hos Claus Hesselberg (s. 3): "'Sandheden' er ikke de faktiske forhold, ikke realiteterne som en eftertids forskere kan redegøre for - western-filmenes sandhed er deres mytiske tradition, en tradition opbygget i takt med filmens historie. « Her er ikke tale om nogen forklaring på noget som helst, men om ren tautologi: filmen har produceret en western-myte, fordi filmen har produceret en westernmyte.

En noget mere interessant og dybtgående, omend også idealistisk, forklaring på western-genrens fascinationskraft leveres af Jean Gili (i Western et chansons de geste, her citeret efter Dort p. 55): „Man taler ofte om episk og om epos i forbindelse med westerns. Denne skulle udgøre en moderne ækvivalent til ridderromanerne og endog til heltedigtene. Dens helt er »det 20. århundredes blændende cow-boy«. Og hans even- 
tyr skulle være en "søgen«. Således skulle det i sidste instans være tilstedeværelsen af det »hellige«, der kunne forklare den lyst, vi føler ved. westerns, den fascination, de udøver over os, samt deres udbredelse såvel i de lokale biografer som i art cinemas.«

Her søges mytens styrke funderet $i$ en a-historisk menneskelig religiøsitet. En kritik heraf vil kunne sætte ind på to punkter: a) en påvisning af religiøsitetens historicitet, et forhold, der falder uden for dette arbejdes sammenhæng, men som jeg må nøjes med at postulere, b) en mere pragmatisk, »tekstnær« kritik, som Dort foretager, og som går på, at western-myten ikke er en Graals-myte. Dermed făr han tilbagevist Gilis konkrete analyse, samt hans metodes anvendelighed i forhold til westerns. Selv om Dort således ikke eksplicit gør op med Gilis metode som sådan, ligger der dog det bredere perspektiv i kritikken, at det ikke er nødvendigt at ty til begreber som »le sacré« for at forklare fænomenet som mytisk fascination.

Endnu tættere på en egentlig forklaring på western-filmens universalitet forekommer det mig, at André Bazin når $(1961 \mathrm{a}, \mathrm{b})$. Bazin har fat $\mathrm{i}$ tre nøglebegreber, som alle må være til stede: myten, historien og filmen: "Western-genrens oprindelse kan føres tilbage til en mytologis møde med et udtryksmiddel: sagaen om the West eksisterede før filmkunstens fremkomst $\mathrm{i}$ litterær eller folkloristisk form, og de kolossalt mange film har slet ikke betydet western-litteraturens undergang; den har stadig sit publikum og leverer stadig de bedste emner til drejebogsforfatterne. Men det begrænsede og nationale publikum til »westernstories« kan selvfølgelig ikke sammenlignes med det verdensomspændende publikum til de film, der inspireres af dem. På samme måde som børnebøgernes miniaturetegninger har været forbillede for katedralernes billedhugger- og kirkerudekunst, udvides denne litteratur, når den er befriet fra sproget, på lærredet, ganske som om billedets dimensioner endelig blev de samme som fantasiens« (1961 a, s. 137, på dansk: s. 98 . Jeg har korrigeret oversættelsen en smule - JT.). Og videre: »Men det ville være lige så forkert at ignorere western-filmens historiske træk som at benægte dens drejebøgers uforstyrrede frihed. J.-L. Rieupeyrout viser os på udmarket måde, hvorledes den episke idealisering af en forholdsvis nær historie opstod, men det er muligt, at hans fremstilling, der især beskæftiger sig med det, som i almindelighed er blevet glemt eller ignoreret, idet den specielt interesserer sig for de film, der kan anskueliggøre den fremsatte tesis, umærkeligt stiller den anden side af den æstetiske virkelighed i skyggen. Den ville ellers give ham dobbelt ret. Thi den historiske virkeligheds forhold til western-filmen er ikke umiddelbart og direkte, men dialektisk. Tom Mix er det modsatte af Abraham Lincoln, men han viderefører dyrkelsen af Lincoln og bevarer mindet om ham 
på sin egen måde. Western-filmen er $\mathrm{i}$ sin mest eventyrlige eller mest naive form lige det modsatte af en historisk rekonstruktion. Hopalong Cassidy synes ikke at adskille sig fra Tarzan ved andet end sit kostume og ved de omgivelser, hvori hans bedrifter finder sted. Hvis man imidlertid vil gøre sig den ulejlighed at sammenligne disse charmerende, men usandsynlige historier, lægge dem oven på hinanden, săledes som man i moderne fysionomik gør med flere ansigtsnegativer, så vil man se en transparens af en ideel western, skabt af de konstanser, der er fælles for de forskellige historier: en western skabt udelukkende af de af dens myter, der findes i ren form « (1961 a, s. 138, på dansk s. 99. Også her har jeg korrigeret den danske oversættelse - JT).

Selv om de tre citerede forfattere (Hesselberg, Gili, Bazin) repræsenterer tre forskellige grader af kvalitet og forklaringskraft, lider de dog af en fælles svaghed: mangelen på en historieteori, der er i stand til at forklare på én gang western-filmen som myte med muniversal appeak samt denne mytes udvikling. Bazin når, som det kan ses af citaterne, længst i sin forklaring. Men det er trods alt ikke alle de dialektiske forhold mellem western-filmen og historien, han får fat i. Han kan derfor ikke integrere mytens forandring, dens udvikling, i sin teori. Bazin arbejder meget korrekt med mytevarianter som varianter over en »arkemyte«, en "western idéal«, eller rettere: i helt Lévi-Strauss'sk forstand arbejder han med warke-myten« som summen af varianterne. Dette er i sig selv en afgørende erkendelse, at kunne skelne mellem en mytes væsen - eller dens konstante elementer - og så denne mytes fremtrædelsesformer. Men lige så vigtigt er det at kunne skelne mellem de fremtrædelsesformer, der er »tilfældige« varianter, og så de ændringer i fremtrædelsesformerne og de ændringer i filmens struktur, der er skabt af ændringer i de historiske forhold, hvorunder de pågældende film er produceret, dvs. skelne mellem tilfældige varianter og historisk betingede forandringer.

På dette punkt kommer selv Bazin til kort. Dette hænger sammen med at den historie, som han mener står i et dialektisk forhold til myten og genren, er den historie, der er mytens/genrens eksplicitte reference: det amerikanske Vilde Vestens historie i det 19. århundrede. Derimod ser Bazin ikke, at også det 20. århundredes historie så at sige er indskrevet i genrens udvikling, og at det således er det 20. århundredes historiske udvikling, der forklarer western-genrens udvikling. Uden på nogen måde at forfalde til platheder a la introduktionen til Sunset Boulevards westernnummer ${ }^{\prime}$ er Bazins forklaringer dog pseudo-forklaringer: " Den fuldkommenhed eller, om man vil, klassicisme, genren var nået frem til, måtte indebære en bestræbelse for at retfærdiggøre dens fortsatte eksistens gennem et eller andet nyt element. Uden at ville forklare alt ved 
hjælp af den famøse lov om de æstetiske tidsaldre, kan det ikke være helt ved siden af at bringe den $i$ anvendelse her $(1961$ b, p. 147, på dansk s. 106 - oversættelsen lettere korrigeret - JT). Og videre: »Med et konventionelt udtryk vil jeg kalde alle de former, genren har antaget siden krigen, for »over-western«... Vi kan sige, at »over-western«-filmen er en western, der skammer sig over kun at være western, og som søger at retfærdiggøre sin eksistens ved også at interessere $i$ anden henseende: æstetisk, sociologisk, moralsk, psykologisk, politisk, erotisk ... kort sagt: ved en vardi, der ikke naturligt horer genren til, men som formodes at gore den rigere» $(1961$ b, p. 147-148. På dansk s. 106. Mine understregninger $-\mathrm{JT}$ ).

Som det fremgår af disse citater er genrens produktionshistorie - den historiske sammenhæng, filmen er blevet til i - kun tilsyneladende til stede i Bazins ræsonnement. Genren har udviklet sig til fuldkommenhed og kan kun fornys gennem kunstig indpodning af problemstillinger, der er fremmede for genren, formidlet via et publikumsforlangende om »noget nyt《. Men indholdet af dette publikumsforlangende er ikke beskrevet, endsige socialhistorisk forklaret. ${ }^{2}$

En sådan socialhistorisk forklaring finder man hos Peter Larsen (1974): „John Fords film Diligencen (Stagecoach) er fra 1939. Det er en western, og det betyder, at der er tale om en historisk film-Diligencen henter sit stof fra nogle sammenstød mellem nybyggere og indianere $\mathrm{i}$ 1870-ernes Arizona. Det vil med andre ord sige, at der på filmens overflade ikke er nogen direkte iagttagelig forbindelse mellem de samfundsmæssige forhold, der fremstilles i filmen, og de hvorunder den er produceret. Hensigten med den følgende analyse er at påvise, hvordan filmens umiddelbare socialhistoriske baggrund (1930-ernes økonomiske krise, new-deal-politikken osv.) alligevel manifesterer sig i filmen og bliver bestemmende for, hvordan det historiske stof organiseres og fortolkes « (Larsen 1974, s. 229).

I Larsens analyse fremstår filmens mytiske diskurs som en (genrespecifik) transformation af samfundsmæssige problemstillinger på filmens produktionstidspunkt. Denne forklaring - og analysen således som den foreligger - forekommer mig yderst givtig og med stor forklaringskraft. Selve Larsens måde at formulere problemet på er en uomgængelig betingelse, hvis man vil ikke blot registrere, men også forklare genrens udvikling. En forklaring af genrens udvikling er umulig, hvis man ikke indreflekterer dens produktions- og konsumtionsbetingelser, dens samfundsmæssige brugsværdi. Hvad der derimod begrænser værdien af Larsens metode er den alt for uformidlede kobling mellem produktions- og konsumtionshistorien på den ene side og filmens fremtrædelsesform på den anden side. Det er kun den enkelte films elementer, og ikke genren 
som sådan og dens konventioner, der er socialhistorisk begrebet. Derved făr Larsen kun forklaret, hvorfor man i 1939 kan lave en film med det af ham beskrevne indhold, men ikke forklaret, hvorfor denne samfundsmæssige problemstilling netop artikuleres i en western. For det andet, og netop af den grund, går analysen glip af væsentlige pointer med hensyn til filmens og mytens specifikke samfundsmæssige betydning, til forskel fra andre udsagns samfundsmæssige betydning. For det tredje og sammenhængende med de to nævnte indvendinger - begår Larsen et par fejlfortolkninger i den konkrete analyse, således som jeg vil vise senere. Og endelig: Larsen får kun forklaret, hvorfor den enkelte film, $D i$ ligencen af John Ford, har en brugsværdi for et amerikansk publikum $i$ 1939, ikke hvorfor den kan have/har en brugsværdi for et ikke-amerikansk publikum og i f.eks. 1977.

Jeg har i det foregående søgt, ved hjælp af en kritisk redegørelse for nogle grundtræk i først og fremmest Bazins og Larsens ræsonnementer, at indkredse to problemstillinger: a) western som en myte, der, på trods af historiske variationer, bevarer en sådan grad af enhed, at man meningsfuldt kan tale om western-genren fra århundredets begyndelse til $\mathrm{i}$ dag, at der altså er tale om en og samme genre. Denne genres fascinationskraft hænger sammen med dens karakter af myte (Gili, Bazin). b) En filmgenres fascinationskraft, en genres (eller enkeltfilms) brugsværdi kan ikke forklares tilfredsstillende uden at medreflektere genrens eller enkeltfilmens historiske produktions- og konsumtionssammenhæng. Endnu mindre kan lovmæssighederne i en genres udvikling forklares uden om denne dimension, uden hvilken filmhistorien vil reduceres til en ophobning af tilfældige og løsrevne fakta. Forskellen mellem de enkelte westerns vil reduceres til tilfældige varianter over en og samme ur-myte. Omvendt kan en socialhistorisk analyse kun se westerngenren/myten som en tilfaldig og uforklarlig fremtrædelsesform for en socialhistorisk problematik, hvis ikke analysen af den enkelte film ser denne inden for rammerne af en genrens socialhistorie, dvs. som et historisk bestemt, ikke-tilfældigt »møde mellem en mytologi og et udtryksmiddel«.

Jeg vil i det følgende betragte western-genren som en epokaltypisk ${ }^{3}$ genre, dvs. en genre, en myte, $\mathrm{i}$ hvis grundstruktur - og altså ikke blot $\mathrm{i}$ variationerne - er indskrevet en socialhistorisk specifik problemstilling. Jeg er enig med Peter Larsen om, at Diligencen artikulerer problemstillinger, der er specifikke for New-Deal-perioden. Men det specifikke ved mytiske artikulationer af konjunktur-historiske indhold er, at disse er historisk bestemte specifikationer/variationer over strukturer, der er "universelle", ikke i betydningen a-historiske, men epokal-typiske, dvs. knyttet til en bestemt historisk epoke, i dette tilfælde kapitalismen. ${ }^{4}$ 
Med denne indfaldsvinkel skulle det således være muligt at forklare western-genrens udvikling efter 2 . verdenskrig, ikke som en »tilfældig« »degenerering«, men som en historisk »nødvendighed er, at en mytes brugsværdi, dens fascinationskraft, beror på dens evne til at artikulere et påtrængende socialhistorisk indhold. Hvis myten i sin oprindelige form ikke formår at artikulere et ændret socialhistorisk indhold, dvs. ændrede livsbetingelser for et samfunds indbyggere (eller for en bestemt klasse, for så vidt der er tale om en klassespecifik myte, ${ }^{5}$ vil den enten uddø eller undergå ændringer, der er af "samme størrelsesorden« som ændringerne i den socialhistorie, den skal fungere i. Ændringerne er således ikke udtryk for en »degenerering«, men for genrens livskraft. På dette punkt er jeg enig med Bazin, men som det vil fremgå af det følgende, er jeg uenig med ham i, at ændringerne er udtryk for en indpodning af "quelque valeur extrinsèque au genre«. Denne opfattelse skyldes, at Bazin ikke har set, at i selve western-genrens grundstruktur fra de tidligere westerns og helt til og med spaghettiwesterns - er indskrevet en specifikt kapitalistisk modsigelse, hvis fremtrædelsesformer ændrer sig afgørende og derfor også må ændre mytens fremtrædelsesform.

\section{Western-mytens struktur}

Grundelementet i western-myten er the frontier, grænselandet mellem civilisation og ødemark, det punkt, der i den amerikanske nybyggerperiodes ekspansion vestpå markerer den yderste grænse for civilisationens fremrykning. Som sådan er der tale om et historisk faktum, der kan registreres i tid og rum, efterhånden som kolonialiseringen rykker frem. Men the frontier er i den amerikanske selvforståelse og i westernmyten mere end civilisationens ydre grænse vestpå: den er det sted, hvor det nye samfund dannes og formes: samtidig med at nyt land, ny vildmark underlægges civilisationen, konfronteres civilisationen, kulturen, ved the frontier, med sin modsætning - og forudsætning - naturen. Eller med andre ord: ved the frontier ophæves modsætningen mellem natur og kultur, naturen kultiveres og samfundet naturliggøres ved at blive fort tilbage til og konfronteres med naturen.

Heri ligger the frontiers mytiske funktion: en naturalisering af samfundsforholdene. Modsætningen mellem det udviklede samfunds modsætningsfyldte egen-logik og dette samfunds »naturgroede« oprindelse er det spændingsforhold, alle westerns direkte eller indirekte tematiserer og opløser i sin mytiske diskurs: „Westerns er en sækulariseret myte, hvor et samfund soger at reflektere sine modsigelser under påskud af at opspore sin oprindelse« (Glucksmann 1966, p. 71). 
Som myte er western-myten altså en oprindelsesmyte, den skildrer en nations - USA's - fødsel, fremkomsten af denne nations institutioner og værdier. Om oprindelsesmyter hedder det i Tegneserier: »Ifølge LéviStrauss . . . er det karakteristisk for mange genesismyter, at deres forklaringer er overordentlig kortfattede i forhold til det, der forklares. Ved nærmere betragtning er det, der kan opfattes som forklaring, ingen forklaring (Prometheus røver en allerede eksisterende ild (vort eks.)). LéviStrauss drager heraf den slutning, at det centrale i disse myteformer ikke er myternes ætiologiske funktion, men deres funktion som betydningsmarkører. Et eller andet nutidigt opnår ved at blive tillagt en oprindelse, en status inden for nutidens betydningssystem i forhold til navne og forhold uden oprindelse « (s. 105).

Denne karakteristik må jeg i lyset af forrige kapitel modificere på en række punkter, når det gælder om at beskrive western-filmen og dens mytiske funktion. På den ene side vil jeg fastholde det aspekt ved oprindelsesmyten som gældende for western-filmen, at den giver nutidige forhold - dvs. forhold på filmens produktionstidspunkt - en betydningsmæssig "markering" ved at henvise til de pågældende forholds oprindelse, en »markering « hvis indhold, jeg vil beskrive grundigere i det følgende, men som jeg på dette sted vil nøjes med at kalde: (forsøg på) ideologisk legitimering. Men på den anden side må jeg hævde netop den ætiologiske (årsagsforklarende) funktion som endog særdeles central for western-filmen, idet det er denne ætiologiske funktions troværdighed, der betinger western-mytens brugsværdi, ligesom det er historisk betingede problemer med at hævde denne troværdighed, der betinger genrens udvikling. Endvidere at det, der bringer denne troværdighed i fare, er de nutidige samfundsmæssige modsætninger, der i stadig ringere grad lader sig ophæve af genrens mytologiske diskurs.

Således kommer den historiske dimension ind i billedet. Westernmytens modsætninger er det kapitalistiske samfunds modsætninger: modsætning mellem simpel vareproduktion og udvidet reproduktion. Jo mere det kapitalistiske samfund udvikler sig, jo større bliver dets modsætninger og jo vanskeligere bliver det at mediere disse modsætninger med oprindelsessamfundets enkle værdier, og jo mere »kompliceret « og »fin-kulturel« bliver genren, - eller omvendt: jo mere degenererer den i trivi-strukturer (om denne tilsyneladende modsigelse, se senere).

I det foregående kapitel talte jeg om en »ren« western-myte, hvis væsen findes bag forskellige historiske fremtrædelsesformer. Imidlertid findes denne »rene« myte kun gennem sine varianter, de konkrete film og evt. i andre diskurser, f.eks. hos den amerikanske historiker $F . J$. Turner. ${ }^{6}$ 
Turners teser om the frontiers betydning for det amerikanske samfund og dets institutioners oprindelse og udvikling er blevet bestridt af mange faghistorikere. ${ }^{7}$ Men i denne sammenhæng vil jeg fastholde Turners tese som stort set identisk med den myte, vi finder i westerns, og det er som sådan den har interesse her. Turners hovedtese er, at det amerikanske samfunds institutioner ikke er importerede fra Europa, men skabt i USA, nærmere bestemt ved the frontier: »Fram till våra dagar har amerikansk historia i hög grad handlat om just den stora Västerns kolonisation. Förekomsten av ett orört, obebyggt område, dess ständiga tillbakaträngande och frammarschen av amerikansk kolonisation västerut, förklarar Amerikas utveckling./Bakom institutioner, bakom konstitutionella ordningar och förändringar, ligger de vitala krafter, som ger liv åt dessa inrättningar och utformar dem för att kunna möta förändrade förhållanden . . . De har tvingats anpassa sig till förändringar i samband med folkets framträngande över en hel kontinent, i samband med övervindandet av vildmark ... «(Turner, s. 142-143).

Det er ødemarkens - den vilde utæmmede naturs - betydning, der her understreges. Dens betydning for det amerikanske samfunds demokratiske institutioner er dobbelt: 1) ved the frontier udvikles en særlig demokratisk - mennesketype: individualisten, der lærer at klare sig selv og spontant modsætter sig politiske påbud ovenfra, eftersom han selv er underkastet en lov, der er stærkere end selv den stærkeste politiske lov og samfundsmæssige magtapparat, naturens lov: „Under denna framryckning är västgränsen den yttre kammen på en våg. Den er mötesplatsen mellan primitivt liv och civilisation... Det mest betydelsesfulla hos den amerikanska gränsen är att den ligger vid den hitre kanten av ett obebott landområde ... /Den berövar honom civilisationens kläder og klär honom i jägarskjorta och mockasiner . . . Hon måste acceptera de villkor, som den er erbjuder, annars dukar hon under. Därför slår hon sig ned i indianernas uthuggningar och följer indianernas stigar. Undan för undan omformar hon vildmarken « (Turner, s. 144-145).

2) På den anden side af the frontier, østpå, findes civilisationen, der hos Turner - som i western-myten - ligesom ødemarken er negativt ladet indtil den omformes gennem impulser fra naturen, formidlet af the frontier: "Att ett område "fritt « land alltid legat invid den västra gränsen för bebyggelse i Förenta Staterna har varit mera betydelsefullt än något annat. Alltid då de sociala förhållandena visade en benägenhet att låsa fast sig i Östern, då kapitalet tenderade att utöva tryck på arbetskraften eller då politiska inskränkningar satte gränser för massans frihet, fanns denna möjlighet till flykt till gränsområdenas fria förhållanden « (Turner, s. 151). Og senere: „Samhället vid östkusten efterbildade den Gamle Världens samhälle i fråga om social struktur och industri 
och började förlora tron på demokratiska ideal. Västern öppnade i stället nya verksamhetsområden och gav ny demokrati till sina mest avlägset liggande domäner. Den skänkte materiella skatter och utövade ett förädlande inflytande på pionjären, som med egen styrke skapat ett hem åt sig själv, byggt en skola och en kyrka og skapat en bättre framtid åt sin familj« (Turner, s. 154-155).

Vi ser således, at hos Turner er demokratiets begreb, med dets individualistiske, frihedselskende mennesketype, knyttet til the frontier: den vilde natur tæmmes og underlægges civilisationen, der på denne måde bliver en »naturlig« civilisation. Men »dessa drag (som) är typiska för gränsområdena . . . kunne också uppstå i andra trakter på grund av att det fanns ett gränsområde« (s. 150). Men civilisationens degenerering lurer som en konstant trussel: klippes denne navlestreng til naturen over, degenererer civilisationen i undertrykkelse, den tvinger mennesket ind i sociale roller, deler det op i klasser, der gør det ufrit.

Filmhistorisk betragtet, og opresumeret til én grundstruktur, består western-mytens »geografi« altså af tre led: odemarken, the frontier, civilisationen. »Udvekslingen« mellem de to yderpoler foregår formidlet af the frontier, der fremstår som en art dialektisk ophævelse af de to poler. Vi ser sjældent i westerns - måske kun i nyere - bycivilisationen eller dens reprasentanter i direkte konfrontation med naturen, f.eks. indianerne, jvf. Soldier Blue m.fl. Derimod ser vi normalt frontier-mennesket som 1) repræsentant for (den allerede transformerede) natur over for civilisationen og som 2) repræsentant for civilisationen over for naturen. Frontier-helten kan - i kraft af den naturlige lov, han reprasenterer - gribe helbredende ind i forhold til den degenererende civilisation, og som repræsentant for civilisationen, menneskeligheden, kulturen, kan han kultivere ødemarken.

Lad os se lidt nærmere på de ydre poler i den mytiske struktur, mellem hvilke den værdimæssige udveksling finder sted:

Ødemarken er civilisationens negation. Her hersker kaos, naturen er grusom og en permanent trussel mod kulturen. Naturens værste trussel mod civilisationen er indianerne - den storste af alle »naturkatastrofer« er indianeroverfaldet, der er lige så uretfærdigt og meningsløst som en hvirvelvind, stormflod el. lign.

Civilisationen, især bykulturen, er western-mytens anden negative pol og i virkeligheden et langt alvorligere problem for denne end ødemarken. Bykulturen er skabt ud fra the frontier, men den har løsgjort sig fra sin naturgroethed, adlyder ikke længere de naturlige love, men selvstændiggjorte samfundsskabte love. Hvor værdier ved the frontier skabes som brugsværdier ved det enkelte menneskes direkte livtag med naturen, er det i byerne, med deres bytteværdiproduktion og pengeøkono- 
mi muligt at tilegne sig værdier uden at udføre naturgroet arbejde. De vigtigste midler hertil er $\mathrm{i}$ westerns: tyverier (fortrinsvis bankrøverier, eller hvis bykulturen rækker sine fangarme helt ud på the frontier: kvægtyveri), kortspil, prostitution og åger/bankvirksomhed.

The frontier er civilisationens vugge. Kampen mod naturen garanterer den samfundsmæssige naturlighed. De barske ydre vilkår sætter en naturlig grænse for menneskelig undertrykkelse og fremmer i stedet menneskelige egenskaber som solidaritet og individualisme. Først samfundets selvstændiggørelse fra naturen, etableringen af en almen ækvivalent, pengene, sætter en modsætning op mellem kollektivitet og individualisme. Hvor eksistensen af ødemarken, dvs. af ejendomslost land, muliggør produktion og tilegnelse af værdier, uden at det bliver på andres bekostning, er den individuelle lov og moral naturlig. I byerne, hvor der ikke findes ejendomsløst land, fører den samme individualisme til udbytning og undertrykkelse.

Ovenpå disse to geografiske og samfundsmæssige poler opbygges to værdisystemer og to lovinstitutioner: den "naturlige « lov ved the frontier og bycivilisationens lov, der er samfundsskabt og derfor unaturlig, underkastet pengenes magt, en lov der tjener samfundsmæssige "klasse«-interesser. I mange westerns er denne spaltning af loven i to love, der henter deres legitimering fra henholdsvis det »naturlige « arbejde ved the frontier og fra klasseinteresserne, manifesteret i en spaltning af lovens institutioner: 1) den retfærdige helt, hvis handlinger henter sin legitimation fra de naturlige omgivelser selv (handlingerne er selvlegitimerende) og 2) sheriffen - the marshall - som repræsentant for den formaliserede lov, der har selvstændiggjort sig fra naturgroetheden og derfor konstant er underlagt truslen om at blive instrument for klasseinteresser og undertrykkelse, - en spaltning der fremstår som en mytisk artikulation af den simple vareproduktions ideal om "natvægterstaten« og den udviklede kapitalismes mere aktivt intervenerende og regulerende klassestat, der ikke er naturligt selvlegitimerende, men - som næunt ovenfor $-\mathrm{i}$ modstrid med the frontiers individualistiske frihedsideal.

Vi er nu nået dertil, hvor det skulle være muligt at formulere, hvad der er den historiske drivkraft i western-genrens udvikling: samfundets selvstandiggørelsestendenser er en fuldbyrdet kendsgerning i det udviklede kapitalistiske samfund, der producerer western-filmen. Derfor er det samfundet på filmens produktionstidspunkt, der i mytisk form artikuleres i og informerer den konkrete udfyldning af den ene pol i mytens univers: bycivilisationen eller dennes institutionelle repræsentanter ved the frontier.

Det skulle således også være muligt at begribe western-filmens brugsværdi, dens mytiske funktion i det 20. årh.: at bygge bro over den mod- 
sætning, der er et grundtræk i og som stadig skærpes i den moderne kapitalisme mellem den (specifikt amerikanske, men mere alment hele den kapitalistiske) ideologiske selvforståelse, byggende på konkurrencens, individualismens og markedslovens optimale, fornuftige selvregulering og på den anden side den kapitalistiske virkelighed: monopolisering, statslig bureaukratisering, udbytning, imperialistisk undertrykkelse, osv.

Western-filmen må således forstås som et »krydsningspunkt« mellem to historier: den historie, filmene eksplicit refererer til og den historie, der skal hente sin historiske legitimering i oprindelseshistorien. I den forstand er western-filmen en oprindelsesmyte. Men i modsætning til oprindelsesmyterne i de af Lévi-Strauss beskrevne samfund, er westernfilmen en kapitalistisk oprindelsesmyte, den nutid der af myten kræver en betydningsmæssig »markering«, ændrer sig stadig på fremtrædelsesplanet, myten må permanent "genskrives« for at bevare sin overbevisningskraft og dermed brugsværdi som myte. I den forstand kan man sige, at genrens udvikling er en »afspejling $\ll^{8}$ af det 20 . årh.'s udvikling, der så at sige indskrives i myten.

\section{Den klassiske western}

På dette sted, hvor jeg har beskrevet western-mytens grundstruktur og angivet dennes historicitet samt nogle rammer for analysen af mytens udvikling og denne udviklings relation til kapitalismens udvikling, vil jeg et øjeblik standse op for at kaste et blik på en klassisk western, John Fords Diligencen.

Uden grundlæggende at ville anfægte Peter Larsens analyse af denne film, er det dog på et andet niveau, jeg vil søge dens historicitet. Larsen finder Diligencens historicitet i det - ubestridelige - faktum, at filmen klart udtrykker en tilslutning til Roosevelts New Deal-politik. Dette forhold er selvfølgelig én af de ting, der knytter filmen til dens produktionstidspunkt, men på dette niveau er der trods alt tale om en tilfoldig relation, eftersom der i perioden produceres mange westerns, hvor denne ideologi - som er en specifik klassesamarbejdsideologi - ikke manifesteres, hverken positivt eller negativt, og vel at mærke: disse westerns er ikke mindre knyttet eller bundet til deres tid af den grund. Det er denne anden binding til produktionstidspunktet, - på et mere fundamentalt strukturelt niveau i filmen end indholdssiden, i selve den æstetiske organisering af mytens grundelementer, - jeg er ude på at indkredse.

André Bazin (1961, b) har understreget den foretrukne brug af total- 
billeder $i$ den klassiske western og set sammenhangen mellem dette og den klassiske westerns episke karakter: »Man tror vistnok i almindelighed, at western-filmen er episk derved, at dens heltes standard er overmenneskelig og deres bedrifter legendarisk store ... Til heltens karakteregenskaber svarer en iscenesættelsesstil, som allerede lader os øjne den episke transponering i billedets komposition, i dens forkærlighed for vidtstrakte horisonter, de store totaloptagelser, som bestandig leder tankerne hen på menneskets konfrontation med naturen. Westernfilmen kender praktisk talt ikke til nærbilledoptagelser, knap nok til optagelser i halvnær; til gengæld har den en udpræget forkærlighed for travelling og panorering, som fornægter lærredets grænser og gengiver den fulde udtrækning./Jo vist. Men denne episke stil făr dog først sin mening gennem den moral, som bestemmer og retfærdiggør den. Det er moralen $i$ en verden. hvor det gode og det onde i samfundet $i$ deres renhed og nødvendighed eksisterer som to ukomplicerede og fundamentale elementer. Men da det gode, som er i færd med at blive til, betinger fremkomsten af loven i sin primitive strenghed, bliver epos'et til tragedie i det øjeblik den første modsigelse opstår mellem den sociale retfærdigheds transcendens og den moralske retfærdigheds specificitet, mellem lovens kategoriske imperativ, som garanterer den kommende bycivilisations samfundsorden og den ikke mindre irreduktible individuelle samvittighed» ((p. 143), på dansk s. 103, oversættelsen en del korrigeret $-J T$.).

Bazin nøjes, som det fremgår af citatet, ikke med at påpege sammenhængen mellem den episke struktur og billedstrukturen. Begge ses som en specifik æstetisk organisering af mytens struktur. Den klassiske westerns univers er et fundamentalt sammenhængende univers, hvis konflikter lader sig løse i et episk forløb.

Det betyder dog ikke, at det klassiske western-univers er konfliktfrit. Tværtimod er westerns kun mulige på basis af en konflikt mellem naturgroethed og social selvstændiggørelse, således som jeg har søgt at vise det $\mathrm{i}$ analysen af mytens grundstruktur, og som det kommer til udtryk i Bazins skelnen mellem social moral og individuel moral.

Med Bazins terminologi består en western-films episke forløb $i$ at formidle modsætningen mellem individuel og social moral. Men jeg kan ikke være enig med Bazin om, at denne modsætning pr. definition er tragisk. Det er den ikke i den klassiske western (i modsætning til i senwesterns og spaghetti-westerns, - men de eksisterede ikke, da Bazin skrev sin artikel), hvilket jeg vil forsøge at vise i forbindelse med Diligencen.

Når modsætningen mellem individuel og social moral ikke er tragisk i den klassiske western, hænger det sammen med, at western-myten 
ikke ser denne modsætning som »skæbne«, men som et historisk pro$d u k t$ af bycivilisationens pengeøkonomi. Følgelig kan modsætningen ophæves på betingelse af eksistensen af bycivilisationens negation, ødemarken. Tragisk bliver modsætningen først i det øjeblik, ødemarken og dermed the frontier - ikke længere findes. Men det problem vil jeg vende tilbage til i forbindelse med sen-westerns og spaghetti-westerns.

I Diligencen findes ødemarken, the frontier og bycivilisationen. Ødemarken er øde, dvs. uden kultur, og fuld af naturlige farer, først og fremmest indianerne, ${ }^{9}$ men bycivilisationen i Tonto viser de første tegn på selvstændiggørelse i forhold til naturen, omend denne selvstændigg ørelse ikke er slet så fremskreden som i mange senere westerns. Men den er der, og det er den, der skaber de modsætninger, der medieres i filmens forløb. Derimod er der tale om en usædvanlig komplet udfoldelse af hele mytens »geografi«.

Dette viser sig allerede i filmens indledningssekvens, ${ }^{10}$ hvor en mellemtekst placerer filmens sted til the frontier og giver en karakteristik af ødemarken: "Indtil Jernhesten kom, var Diligencen det eneste rejsemiddel på den utæmmede amerikanske frontier. Trodsende alle farer bragte disse Concord coaches - den tids "streamliners « - vilde og øde ørkenstrækninger og bjergområder i det sydøstlige USA ind under den samfundsmæssige tidsrytme (spanned on schedule). I 1875 var indianernes forbitrede kampe for at smide de hvide indvandrere ud ved at nå deres højdepunkt. På den tid var der intet navn, der fyldte de rejsendes hjerter med mere rædsel end GERONIMOs - lederen af de apacher, der foretrak døden frem for at underkaste sig den hvide mands vilje (Ford \& Nichols, s. 25).

Ødemarkens truende karakter er således klart markeret allerede her, men temaet tages op gennem hele filmen ved hjælp af forskellige teknikker: 1) I en række »sekvenser " " efter diligencens afgang fra Tonto, foretages kontrastklipning mellem »nærbilleder « (egentlige nærbilleder og plans américains) fra diligencens indre til »totalbilleder « (long og medium shots, ifølge manus) af landskabet, hver gang »igangsat « af samtaler/udsagn af truende karakter. Gennem disse klip »overføres« samtalens skæbnesvangre og truende karakter til landskabet;122) Da indianerne første gang ses i samme "rum" som diligencen, etableres kontakten gennem en - med rette meget berømt - kamerapanorering. Panoreringen konnoterer - i modsætning til et klip, der ville have haft samme denotationsindhold - her en understregning af, at diligencen og indianerne befinder sig i samme "rum «; 3) Diverse rogskyer undervejs, overfaldet ved East Ferry; 4) Indianeroverfaldet.

Men er ødemarken truende og farefuld, er bycivilisationen ikke mindre problematisk, idet vi her, som nævnt, finder en begyndende 
selvstændiggørelse af denne $\mathrm{i}$ forhold til det »naturlige« frontier-samfund, repræsenteret ved Ringos og Dallas' drøm om egen ranch (småborgerlig simpel vareproduktion). I Tonto manifesteres denne begyndende selvstændiggørelse ved 1) skabelsen af en samfundsmæssig rigdom, baseret på pengeøkonomi, der giver grobund for en unaturlig civilisation: banker (pengespekulation), spil (om penge), prostitution (for penge). 2) Denne samfundsmæssige selvstændiggørelse giver anledning til klassepolarisering mellem samfundets indbyggere: muligheden for at tilegne sig værdi uden at producere brugsværdi i direkte livtag med naturen, deler samfundet i dem, der profiterer på pengeøkonomien (bankmanden Gatewood), dem der er dens ofre (luderen Dallas) og nogle derimellem (spilleren Hatfield og whiskyhandleren Peacock). 3) Den samfundsmæssige selvstændiggørelse fører endvidere til en selvstændiggørelse af moralen som et mål i sig selv/selvretfærdig bedreviden, manifesteret forst og fremmest ved the Law-and-Order-League, en social moral, der er lige så grusom for dem den går ud over, som indianerne, jvf. Dallas: »There are worse things than Apaches« (Ford \& Nichols, p. 49). 4) Parallelt med den samfundsmæssige selvstændiggørelse, klassepolariseringen og den moralske selvstændiggørelse, er der kim til spaltning af lovinstitutionen $\mathrm{i}$ to: en der repræsenterer den sunde frontier-lov og -moral og en, der stiller sig i den selvstændiggjorte bymorals og klasseinteressernes tjeneste.

Filmens episke forløb består nu i at nedbryde denne samfundsmæssige selvstændiggørelse ved at føre samfundet tilbage til dets naturlige udgangspunkt og rødder. Dette gøres i Diligencen helt symbolsk ved at anbringe alle kategorier af byboere i en diligence, der kører fra én by til en anden langs med the frontier for dér at stille menneskene ansigt til ansigt med Naturens fundamentale udfordring.

I denne konfrontation med Naturen genvinder Kulturen sin sund-

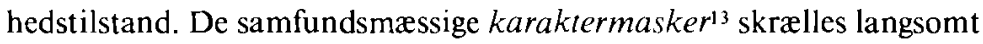
men sikkert af individerne, efterhånden som det viser sig, at de er en hemsko for at bekæmpe den ydre fare og i det hele taget forholde sig adækvat i forhold til the frontiers absolutte betingelser: Liv (fødslen) og Død (indianeroverfaldet). Det lykkes at bekæmpe den ydre fare, i og med karaktermaskerne kastes. Samtidig uddrives det onde af civilisationen, og det naturlige forhold mellem menneskene genoprettes.

I sin ellers fortrinlige analyse af Diligencen underbetoner Peter Larsen på en mærkværdig måde the frontiers funktion i filmens forløb, hvorved han også mistolker forholdet mellem by og ødemark. Peter Larsen skriver: $\gg \mathrm{Da}$ de amerikanske nybyggere i sin tid underlagde sig de store uopdyrkede landområder mod vest, kom det ofte til voldsomme sammenstød med landets oprindelige beboere, indianerne. Indenfor 
western-traditionen gengives disse sarnmenstød normalt set ud fra nybyggernes synspunkt: deres små byer og militær-fortene fremstilles som de gode, sikre steder midt $\mathrm{i}$ en vild og ond natur . . . Diligencen falder $\mathrm{i}$ $\sin$ fremstilling uden for dette mønster: dels foretages der i filmen en noget anden værdisætning af de geografiske områder - dels spiller selve indianeroverfaldet ikke nogen særlig central rolle i forløbet ... For de personer, der rammes af byborgerskabets moralske forargelse udgor byen ikke noget positivt alternativ til den negativt beskrevne natur. de er på vej ud i. . . Indianeme reprasenterer på denne måde ikke noget nyt - der er blot tale om en tilspidsning af forhold, der allerede ligger $\mathrm{i}$ bylivet « (Larsen, s. 229-231).

For det forste er jeg her uenig med Larsen om den generelle karakteristik af western-traditionen (jvf. afsnittet om western-myten) og dermed $\mathrm{i}$ påstanden om, at Diligence'n falder uden for det traditionelle mønster. For det andet er det en katastrofal fejltolkning, at indianerne »blot« udgør »en tilspidsning af forhold, der allerede ligger i bylivet «. Der er tale om to forskellige onder. Naturen er ond, for så vidt den er farefuld (indianerne). Men også bycivilisationen med dens pengeøkonomi er ond og kan kun reddes eller helbredes af »naturen « gennem uddrivelse af det »samfundsmassigt onde« (spillet, prostitutionen, spekulation) ved hjælp af en helt, der representerer mnaturens/the frontier (Ringo), samtidig med at det lykkes »kulturen« at besejre den negative "natur« (indianerne). Denne dialektik mellem »natur og »kultur« kan kun etableres ved the frontier. Men selve diligence-temaet implicerer jo også, at den negative bycivilisations repræsentanter rykkes ud af byen og sættes $i$ en »frontier«-situation, dvs. en situation, hvor de må udvikle deres »naturlige« menneskelige kulturegenskaber. De fleste bestăr denne prøve og beviser derved indirekte, at det "onde« ikke ligger $\mathrm{i}$ individerne, men er samfundsskabt. Også i denne forstand har Dallas ret, når hun siger, at der er "worse things than Apaches«. For netop kampen mod Apacherne giver menneskene mulighed for at vise deres »sande natur « og bygge en »naturlig« civilisation.

Denne frontier-situationens helbredende funktion i forhold til civilisationen vil jeg søge at uddybe i forhold til Diligencens skildring af lovinstitutionen, der ikke forekommer helt entydig, men som jeg vil prove at tematisere:

Lovinstitutionen er tendentielt spaltet op i to: den naturlige frontierlov, repræsenteret ved Ringo Kid, som er den der sejrer til sidst, da det er dén, der uddriver det onde, og i en formaliseret sherif-institution, der er lidt mere tvetydig. Det er således sheriffen i Tonto, der korporligt forer Dallas til diligencen. Den er således i ledtog med "Law-and-OrderLeague«. Men samtidig er det sheriffen i Lordsburg, der arresterer Gate- 
wood. Forklaringen på tvetydigheden ligger måske i, at sheriffen både er integreret i den »onde « civilisation, men samtidig skal bekæmpe denne ondskab. ${ }^{19}$ Men hvis vi ser forløbsmæssigt på problemet, kan vi konstatere følgende: 1) Først uddriver sheriffen Dallas fra Tonto (negativt), så 2) arresterer sheriffen, Curley, Ringo (neg.), men for at beskytte ham (pos.), dvs. alt i alt tvetydigt, 3) endelig loslader Curley Ringo for at han kan gøre op med Plummer-brødrene, og sheriffen i Lordsburg arresterer Gatewood (pos.). Sherif-institutionen gennemløber således tre stadier: 1) negativt (før diligenceturen), 2) negativt og positivt (under turen), 3) positivt (efter turen). Men i det hele taget er sherif-institutionen sekundær: den henter sine negative eller positive træk fra den sociale praksis, den fungerer i: 1) i ledtog med og underordnet »det onde « $i$ civilisationen, 2) under turen(s forste del) formidler mellem de forskellige interesser (opfordringer til at løse konflikterne ved afstemninger), 3) det er ikke sheriffen, men Ringo, der uskadeliggør Plummer-brødrene, men han sanktionerer Ringos handlinger.

Jeg håber, i det foregående - der ikke giver sig ud for at være en udtømmende analyse af filmen - at have påvist, at Diligencen artikulerer western-myten i relativt ren form og uden væsentlige komplikationer. ${ }^{15}$

Sammenfattende vil jeg karakterisere filmen ved: 1) André Bazins karakteristik af western-moralen som »moralen $i$ en verden, hvor det gode og det onde i samfundet $i$ deres renhed og nødvendighed eksisterer som to ukomplicerede og fundamentale elementer«, 2) ved universets fundamentalt sammenhængende og gennemskuelige karakter, 3) forløbets deraf følgende episke karakter: să snart personerne rykkes ud på the frontier, drives de ikke af social tvang og sociale erfaringer, men af naturens udfordringer. Nok »ændrer « personerne sig, men der er ikke tale om en udvikling (som $i$ en roman), men om en transformation fra den samfundsskabte karaktermaske til den rene Menneskelighed. 4) Til dette fundamentalt sammenhængende og gennemskuelige univers svarer en billed-og montageastetik, domineret af total-og halvtotalbilleder: der er ingen "fremmedgjort afstand « mellem individerne og naturen. Montagens eneste funktion er rytmisk at understøtte og dramatisere narrationens episke forløb, med varieret udnyttelse af de klassiske. storsyntagmatiske figurer.

\section{Western-genrens udvikling}

Năr jeg i det følgende vil gennemgå western-genrens senere udvikling. vil jeg ikke gå så detaljeret til værks, som tilfældet var med Diligencen. I stedet vil jeg koncentrere mig om de samfundsmæssigt bestemte trans- 
formationer, der finder sted af mytens struktur og af dens æstetiske iscenesættelse. Jeg vil forsøge at vise, hvorledes den socialhistoriske udvikling griber omdefinerende ind i western-genrens a) personkarakteristik, dens opfattelse af forholdet menneske/samfund/natur, dvs. dens subjekt-objekt-problematik, b) narrative strukturer, en udvikling Dort karakteriserer som en udvikling fra episk struktur til romanstruktur, c) billed-og montagestrukturer, hvor udviklingen karakteriseres af en øget - eller i hvert fald anderledes og mere prægnant - brug af nærbilleder og montage.

For at beskrive udviklingen af western-filmen efter 2. Verdenskrig vil jeg opdele den i forskellige undergenrer, idet jeg - på trods af forskelle og udvikling - regner alle westerns fra før 2 . Verdenskrig til kategorien klassisk western. De undergenrer, jeg vil operere med, er:

a. Overwesterns - westerns efter 2 . Verdenskrig, sidste halvdel af 40'erne, 50'erne og begyndelsen af 60'erne.

b. Sen-westerns - 60'erne og 70'erne.

c. Spaghetti-westerns - westerns produceret i Europa i samme periode som sen-westerns.

Hertil kommer et andet fænomen fra slutningen af 60'erne og 70'erne, nemlig western-komedier, som kun vil fẩ en meget kortfattet kommentar.

Denne faseopdeling skal ikke opfattes som noget absolut. Der er lavet westerns efter 2. Verdenskrig, som ud fra mine definitioner kun kan opfattes som "klassiske«, f.eks. Hawks' El Dorado fra 1967 (altsă midt $\mathrm{i}$ "sen-western-perioden «, ${ }^{16}$ og der findes spirer til over-western-problematik i westerns før 2. Verdenskrig. Endelig er jeg tilbøjelig til at betragte udviklingen i John Fords westerns som en selvstændig udvikling, der mindre end andre westerns lader sig indfange af de formelle klassifikationer, selv om også denne udvikling er styret af de samme kræfter som genren som helhed.

\section{Over-westerns}

Karakteristisk for de forskellige western-typer efter 2 . Verdenskrig er et sammenbrud for epos-strukturen, af mytens sammenhængende og umiddelbart gennemskuelige univers, af den klassiske westerns subjektobjektrelation: hvor karaktermaskerne umiddelbart faldt bort i Diligencen, så snart individerne blev konfronteret med the frontier, er dette ikke tilfældet mere. Tværtimod kendetegnes over-westerns af den problematiske helt (Goldmann), dvs. et individ, der kun vanskeligt formår at leve op til og tilpasse sig frontier-betingelserne. Denne tilpasning ta- 
ger ofte form af en læreproces som i Hathaways En mand jages (1958) og Nevada Smith (1966), dvs. helten må gøre nogle sociale erfaringer. Det gode og det onde er ikke længere noget der findes som sto ukomplicerede og fundamentale elementer « (Bazin 1961 b). Den sociale lov og den individuelle lov kan kun med stort besvar og med mange medieringer bringes i overensstemmelse med hinanden, uden at der dog endnu helt er tale om en tragisk modsætning. Konfliktstoffet mellem det gode og det onde er ikke umiddelbart gennemskueligt og muligt at gennemspille $\mathrm{i}$ et episk forløb. Tværtimod internaliseres konflikten ofte til at blive et samvittighedsspørgsmål for helten.

I Nevada Smith manifesteres dette ved at helten, på hvert enkelt stadium i.sit projekt - at hæune den grusomme massakre, der blev begået mod hans forældre - standser op for at føre lange diskussioner om hævnens berettigelse og retfærdighed. På to niveauer viser lovens og moralens manglende "naturlighed« sig: 1) Helten er ikke umiddelbart i stand til at handle adækvat, men må forst gennem en indviklet læreproces tilegne sig de nødvendige færdigheder, såvel af teknisk art: skyde, spilie kort, drikke, som af mere social art: selvbeherskelse, evne til at kontrollere sin spontaneitet for bevidst at kunne lede den ind i hensigtsmæssige baner, lære ikke at stole på nogen, for folk er ikke hvad de giver sig ud for, heller ikke på the frontier. Tværtimod er the frontier befolket af tvivlsomme og samfundsmæssigt definerede individer, dvs. karaktermasker, som man må lare at gennemskue. 2) For det andet tager hævnonsket mere og mere tydeligt karakter af et traume, som helten for sin egen sjælefreds skyld må have udløsning for.

I En mand jages findes en lignende problemstilling. Men her er det sine umiddelbare instinkter og holdninger til, hvad der er godt og ondt, helten må gore op med i én lang social læreproces, der er filmens tema. Helten kan ikke problemløst varetage sin funktion som western-helt, men er placeret i den ene valgsituation efter den anden mellem modstridende elementer i værdisystemet: mellem respekten for liv og nødvendigheden af at dræbe for at beskytte sin familie.

Konflikten udløses ved at helten ved et uheld dræber kapitalistens søn og nægter at forsvare sig effektivt ved at dræbe kapitalistens håndlangere. Kapitalisten har opbygget sin virksomhed for »at sætte sit mærke på verden«. Dette mærke kan kun fastholdes, ved at kapitalen fortsætter intakt i familiens eje (under samme navn). Kapitalisten siger eksplicit, at drabet på sønnen er et angreb på kapitalen og derfor må hævnes. Dermed er heltens ønske om at forsvare $\sin$ (kommende) familie blevet antagonistisk i forhold til hans værdisystem og til kapitalen. Men i slutopgøret bliver det "familien «, der medierer konflikten: helten redder kapitalistens anden søns liv, og kapitalisten skăner heltens liv af 
familiefølelse: helten har trods alt ved at redde den anden søn muliggjort kapitalens fortsættelse. Derved undgås den konfrontation, der kunne føre til likvidation af kapitalen eller af (heltens) familie.

I en tredie berømt over-western, George Stevens' Shane - den tavse rytter (1953) er det selve mytens geografi, der tenderer til at bryde sammen. Konflikten står her mellem nogle ranch-ejere ved the frontier og en kvægkonge i den nærmeste by, der ønsker at fordrive nybyggerne fra deres jord, for at hans kvæg kan græsse på den. Den moralske konflikt opstår ved at begge parter føler sig som de sande nybyggere og frontierindivider. Kvægkongen har erobret landet (ødemarken) fra indianerne og har endnu resterne af en pilespids $i$ armen. Han opfatter ranchfolkene som nogle, der trænger ind på hans land for at erobre det fra ham. Ranch-ejerne er dem, der opdyrker og kultiverer ødemarken, udfører naturgroet arbejde og producerer umiddelbar brugsværdi i direkte livtag med naturen, mens kvægkongen er blevet rig på at handle med kvæg og levere kød til de store byer. Konflikten er altså ikke så gennemskuelig som i Diligencen, moralsystemets værdisætning ikke så klar, omend det dog er de små ranch-ejeres naturgroede arbejde, der har filmens sympati. Det lykkes at udrydde kvægkongen og den lejemorder, han har hyret for at bevare sin monopolstilling til jorden.

Sammenhængende med det delvise moralsammenbrud er det også karakteristisk, at ranch-ejerne ikke selv udvikler de egenskaber, der skal til for at forsvare sig mod kvægkongen. Denne udryddelse foretages af den ukendte Shane, om hvem det antydes at han er på flugt fra en tvivlsom fortid. Han ønsker at slå sig ned blandt bønderne $\mathrm{i}$ håb om dér at kunne leve et hæderligt og uproblematisk liv efter de gamle frontieridealer. Hans lod bliver nu den at fjerne kvægkongen i en voldsom skudduel, dvs. bane vej for en sikring af bønderne, men uden selv at kunne integreres. Han rider bort over prærien med ordene: "Jeg må videre. Man kan ikke ændre sig selv. Jeg forsøgte, men det var forgæves. Der er ingen vej tilbage. «17

Sammenfattende vil jeg om over-westerns konkludere: Moralsystemet tenderer til at bryde sammen, værdierne er ikke umiddelbart gennemskuelige, medieringen mellem frontier-idealerne og den samfundsmæssige realitet lader sig kun vanskeligt gennemføre. Helten bliver en problematisk helt, det narrative forløb tager romanagtig form, for at muliggøre heltens nødvendige sociale læreproces og/eller artikulationen af det komplicerede moralsystem.

Hvilke socialhistoriske og socialpsykologiske forhold er det, der har nødvendiggjort denne ændring af genren? For der er ikke - som hævdet af Bazin - tale om, at filmen på udvendig måde tilføres problemstillinger, som er fremmede for genren. Det er tværtimod mytens grundele- 
ment, the frontier, der er undergået transformationer.

For at besvare dette spørgsmål er det nødvendigt at fastholde, at western-myten er en kapitalistisk myte. The frontier er et mytisk tegn for nogle sociale forhold, der har ændret sig så meget, at myten problematiseres af det. Jeg har beskrevet western-myten som et $» k r y d s n i n g s-$ punkt« mellem to historier: det 19. og det 20. århundredes, og defineret genrens sociale funktion som den at reintegrere massernes umiddelbare erfaringer i nationens selvforstålse. The frontier, som det centrale tegn i myten, er en fortatning ${ }^{18}$ af elementer i såvel 1) massernes erfaringsverden: mulighed for individuel ekspansion, dvs. for at etablere sig selvstændigt med småborgerlig produktion (småhandel, håndværk, familielandbrug) som i 2) nationens selvforståelse: muligheden af ekspansion (økonomisk, handelsmæssigt, politisk, osv.). Anfægtes blot ét af disse sociale forhold - for ikke at sige dem begge - vil der være tale om en anfægtelse af myten, dvs. af 1 ) den selvforståelse, der binder individernes individuelle stræben til nationens idealer, eller 2) af den ideologiske legitimering af USA's internationale rolle (imperialismen).

Under og efter 2. Verdenskrig sker der store forandringer på netop disse to områder. I sâvel USA som i hele den øvrige højtudviklede kapitalistiske verden finder der en voldsom reorganisering sted af hele produktionsstrukturen, med omfattende udradering af den småborgerlige produktion til følge (se $\mathrm{Mandel}$ ). Individernes livsbetingelser og fremtidsudsigter forandres radikalt: produktionscentralisering, automatisering, rationalisering, udbygget arbejdsdeling, uigennemskuelige og abstrakte arbejdsprocesser. Det er altsammen ting, som indledes i denne periode og gør det sværere for masserne realistisk at se en lysende fremtid $i$ at etablere sig med selvstændig småborgerlig produktion, - et forhold der nødvendigvis må manifestere sig i en så vigtig publikumsgenre som westerns, hvis masserne skal kunne genkende deres egne forhåbninger og frygt i filmen.

For det andet ændres USA's rolle internationalt. USA bliver verdens klart dominerende kapitalistiske magt og »verdens politibetjent « med de problemer og legitimationsvanskeligheder, der følger heraf: i denne periode (slutningen af 40'erne og 50'erne) først og fremmest $i$ form af Koreakrig og McCarthy'isme. Betydningen af USA's nye imperialistiske rolle viser sig dog først for alvor i westerns i 60'erne og 70'erne med fremkomsten af sen-westerns.

\section{Sen-westerns}

Den udvikling i retning af opløsning eller komplikation af frontiermyten, som jeg beskrev i forbindelse med over-western-genren i 50'er- 
ne, fortsætter og radikaliseres drastisk i 60'ernes og $70^{\prime}$ ernes senwesterns. Den problematiske helt bliver her endnu mere problematisk, nærmest en anti-helt. Den narratologiske romanstruktur bibeholdes, men hvor medieringen $\mathrm{i}$ over-westerns, trods alle vanskeligheder, lykkes, så mislykkes den i sen-western-genren: modsætningen mellem den individuelle og den sociale moral bliver tragisk. Hvor helten i overwesterns ikke var umiddelbart integreret $\mathrm{i}$ omverdenen, men mătte tilkæmpe sig denne integration gennem en social læreproces, er denne integration nu umulig, hvilket ofte manifesteres $i$ den billed-og montagemæssige iscenesættelse (herom senere).

Disse ændringer vil jeg soge at vise $\mathrm{i}$ forbindelse med nogle karakteristiske sen-westerns: Peckinpahs De red efier guld (1962) og Junior Bonner (1972), ${ }^{19}$ Monte Hellmans Tre lovlose (1965) samt, meget kort, James Neilsons Soldier Blue (1970). ${ }^{20}$

l sen-westerns er the frontier ikke liengere stedet, hvor den sunde og naturlige kultur opstår, eller den findes, som hos Peckinpah, knap nok mere: hans westerns foregă $\mathrm{i}$ slutningen af det 19. århundrede, hvor hele Vesten allerede er koloniseret, og der derfor ikke længere findes nogen ødemark. Hans »helte« er derimod - i De red efter guld og Den vilde bande - aldre mænd, der har levet deres liv ved the frontier. men som nu ikke læengere kan finde sig til rette $i$ et samfund uden frontier. Deres idealer og livsstil er blevet anakronistiske.

Denne tidsmiessige forskydning af handlingen, med den deraf følgende ændring af mytens geografi, er ikke tilfældig. Den er produceret af western-publikummets nye livssituation i 60'erne og 70'erne. I disse årtier fortsætter den sociale udvikling, jeg kort beskrev i forbindelse med over-westerns, med stormskridt. Der er ikke megen plads for frontier-idealer i den sociale virkelighed: drømmen om det enkelte individ, der bygger sit samfund op fra iligenting i direkte livtag med naturen, er en absurd anakronisme. Individerne står overfor en allerede fororganiseret fremmed social realitet, hvor man mă finde sin plads eller gå til grunde. Ganske vist forsøger John F. Kennedy i sin valgkampagne for præsidentposten at genoplive og mobilisere frontier-idealerne i sit program om wthe new frontier«. Men herved henviser han til rumprogrammer (der kulminerer i landsætning af mennesker på månen) og til et program for opbygning af en velfærdsstat gennem statslig intervention. Der er altså tale om projekter, der kræver helt andre egenskaber end nybyggerens, baseret som de er på højtudviklet teknologi, specialiseret arbejdsdeling og statslig organisering.

Frontier-mytens andet element, nationens ekspansion, bliver i 60'erne og 70'erne ikke mindre undermineret: USA's selvforståelse som international garant for frihed (»den fri verden «) over hele kloden, afslø- 
res som et ideologisk røgslør over imperialisme og undertrykkelse: Svinebugtaffæren, Santo Domingo, samt, helt afgørende, Vietnam og Chile. Samtidig gor de undertrykte nationale minoriteter i USA, fremfor alt de sorte, men også chicanoerne, indianerne o.a. oprør mod »den indre kolonisering «.

Alle disse ting medfører et radikalt behov for at "genskrive « historien og myten for at bringe den i relation til og gøre den virksom i forhold til den sociale og politiske realitet. Dvs. mytens sandhedsværdi må undersøges nærmere. Med Dort's formulering: »Hele western-filmens moderne udvikling . . . priviligerer Historien på mytens bekostning« (Dort p. 64). Så stor værdi tillægges den mytiske markering af nutidsforholdene åbenbart, at man tilsyneladende foretrækker at genskrive myten kritisk, at »afsløre « den, fremfor at stå uden »genesis-markering« af den sociale realitet i 60'erne og 70'erne. Det siger noget om western-mytens styrke og socialpsykologiske betydning.

Jeg vil nu nærmere undersøge, hvorledes disse forhold artikuleres i de omtalte westerns. I Peckinpah's De red efter guld er »heltene« ikke »oppe imod « indianerne, men mod et gennemorganiseret samfund, totalt baseret på pengeøkonomi. Hvordan kan frontier-idealerne realiseres i et sảdant samfund? Er det overhovedet muligt? Filmens to whelte« har $\mathrm{i}$ filmens start forsøgt sig med hver sin udvej. Den ene har gjort sine frontier-erfaringer til show: han rejser rundt til byerne og opfører et wildwest-show, ${ }^{21}$ mens den anden rider rundt, uden reel kontakt med virkeligheden, og leder efter en mulighed for at bruge sine erfaringer i en social praksis.

"I romanen finder der en adskillelse sted mellem mening og eksistens«, skriver Dort (p. 67). "Heltene» forsøger nu sammen at bringe sammenhæng mellem idealer og social praksis. Chancen byder sig tilsyneladende, da de hyres til at hente noget guld fra nogle guldgravere og føre det til banken. Men da den sociale basis ikke er til stede for en sammenhængende frontier-moral, splittes dennes elementer op på de to personer. Den ene (Randolph Scott) satser på elementet »erobring«. Men hvordan erobre ejendom, når der ikke er nogen ødemark, og alt derfor allerede er (andres) ejendom, om ikke ved at stjæle. Den anden (Joel $\mathrm{McCrea}^{22}$ ) satser på elementet »beskyttelse« af den betroede ejendom mod ydre farer og stiller resigneret sin skyde- og ridefærdighed i bankens tjeneste som lønarbejder.

For en tid lykkes det dem hver for sig at drømme sig tilbage og forestille sig, at de stadig er ved the frontier, men de rider gennem de vilde og uopdyrkede skove og bjerge, mens drømmenes manglende realitet konnoteres af skovenes gule efterårsfarve og det lidt latterlige og forslidte undertøj, de gamle »helte« går rundt i ved lejrbålet. Modsætningerne 
er rragiske, det lykkes ikke at mediere dem til en meningsfuld og sammenhængende social praksis. Personligt bliver opgaven dog i en vis forstand et højdepunkt i deres »karriere«, da de i en gigantisk klassisk revolverkamp besejrer nogle guldgravere. der vil bortføre en ung pige efter at have myrdet hendes fader. ${ }^{23}$ Joel McCrea dør på klassisk westernvis "på toppen« og med forvisning om, at han altid har været en ærlig mand og om, at hans ansvar overfor banken opfyldes, da Randolph Scott lover at gøre jobbet færdigt: McCrea skal ikke dø forgæves: venskabet og solidariteten er vigtigere end »erobring«, selv om det kun bliver meningsfuldt gennem resignation i forhold til omverdenen.

I Junior Bonner finder vi en endnu større afstand mellem idealer og virkelighed end i De red efter guld, da filmen foregår i vore dage og skildrer western-mytens skæbne og degeneration i den moderne verden. Filmens tre mandlige medlemmer repræsenterer tre forskellige »degenerationsstadier «: 1) Faderen Ace: for ham er frontier-idealeme stadig virkelige, han vil realisere dem reelt, men kan det ikke i det moderne samfund og drømmer derfor om at emigrere til Australien i håb om der at finde en frontier og en ødemark. 2) For sønnen Junior Bonner er idealerne også alvor, men han vil realisere dem her og nu og gøre det eksistenticlt, i rodeoen, hvor det er livet der står på spil, hver gang han kæmper med de vilde heste og tyre. Men der er trods alt tale om show: kampen med hestene og tyrene tjener ikke til at opbygge et nyt samfund, men er fritidsfornøjelse for et publikum. Denne show'-karakter understreges i filmens billedstruktur, mest radikalt under forteksterne, hvor lærredet splittes op i dele, der viser forskellige enkeltbevægelser, som »fryses«. Kampen med naturen (tyrene og hestene) er blevet en selvstandiggjort gestus, løsrevet fra en meningsfuld social praksis. 3) Den anden søn, Curley, er helt på det moderne samfunds side: for ham er det vilde vesten ren og skær forretning. Han nedbryder de fă rester, der er tilbage fra frontier-tiden (forfaldne rancher) og indretter områderne som camping-pladser, hvor folk $\mathrm{i}$ fritiden kan komme $\mathrm{i}$ den moderne prarievogn, campingvognen, og lege Wild West. Moderen bliver til overs, fordi idealerne ikke kan realiseres ved en eksisterende frontier på en ranch, men projektet må hele tiden påbegyndes igen under ny' former, en proces som kvinden i westerns er lukket ude fra. Hun er på Ace's og Juniors side, men mă acceptere Curleys virkelighed.

Peckinpah's westerns har en udpræget nostalgisk tone, der kommer af, at hans tema er mytens sammenstød med en tid, hvor den er blevet anakronistisk. Hans personer tror på myten og er parat til at sætte livet på spil for idealerne. Filmene er tragiske, fordi modsætningen mellem idealer og virkelighed er uovervindelig. Men mytens gyldighed »som sådan« anfægtes ikke. 
Hos Monte Hellman er det derimod selve myten om the frontier, der destrueres. I Tre lovlose forfølges tre uskyldige mand tilfaldigt, mistankt for at have begået et diligenceoverfald, de intet har haft med at gøre og intet kender til. De forfulgte, såvel som forfølgerne, er fanget ind $i$ et spil, som ingen af dem kan gennemskue. De har ingen mulighed for at bryde igennem det tilsyneladende og etablere en gennemskuelig relation mellem godt og ondt, sandt og falsk. Sandheden kommer aldrig for dagens lys. Selv i forhold til frontier-bonden kan de ikke gøre den del af sandheden, de selv kender, troværdig. Helten er tragisk: han dør i forsøget på at klargøre sandheden om sin og sine venners uskyld.

Lige så stor usikkerhed hersker der om, hvem forfølgerne egentlig er. Er det en sherif og hans possey? Nogle ting tyder på det, andre på at det ikke er tilfældet. Lederen af forfølgerne sidder på et tidspunkt uden for sit hus på verandaen $\mathrm{i}$ en stilling. der gennem utallige westerns (f.eks. Wyatt Earp i My Darling Clementine og McCabe i Two Rode Together) er blevet et slags fast symbol på sheriffen. Men han bærer ikke stjerne og han hænger folk (necktieparty, som en af de forfulgte galgenhumoristisk kalder det) uden nogen form for justits, altså foretager selvtægt. Alt i alt er lov-institutionen under alle omstændigheder totalt uigennemskuelig.

Virker handlingen og moralsystemet således totalt abstrakt, uigennemskueligt og uvirkeligt, er lyden af Winchester-riflernes piften til gengæld yderst realistisk. Vi finder her en lydlig æstetik, der helt minder om den, man finder i spaghetti-westerns. Men i modsæetning til disse, er der ikke tale om en skyderitualets æstetik: hverken forfølgerne eller de forfulgte skyder sarlig godt, og de forskellige gestus er ikke specielt æstetisk iscenesat.

Hvor De red efier guld og Junior Bonner skildrer degraderede integrationer af idealerne i socialiteten, dvs. de er uvirkelige, skildrer Peckinpah's Den vilde bande (1969) og George Roy Hills Butch Cassi$d y$ and the Sundance Kid (1969) nogle mennesker, der søger at leve frontier-elementet »erobring« ud ved den gamle frontier, men på et tidspunkt, hvor hele samfundet er gennemorganiseret og uden plads for frontier-helte. Her slutter »heltene« ikke »på toppen« i klassiske revolverdueller, men de mejes ned af maskingeværer i kolossale blodbad, æstetisk iscenesat med udviklet farveteknik og slow-motion, hvor blodbadet selvstændiggøres til "æstetik«, dvs. er socialt meningsløst, men fundamentalt tragisk.

Alle de hidtil omtalte westerns artikulerer den del af frontier-tegnets elementer, der henviser til individernes livsvilkår. I modsætning hertil relaterer Soldier Blue åbenlyst til USA's internationale rolle. Her "genskrives« oprindelsesmyten $\mathrm{i}$ lyset af Vietnamkrigen. ${ }^{24}$ Her er ikke tale om, at nybyggerne opdyrker en ødemark, men om at kolonisatorer med 
en overlegen hær i ryggen, voldeligt destruerer en højtudviklet værdifuld kultur, indianernes. Her undermineres frontier-myten på anden vis end i de tidligere omtalte film: forestillingen om en ødemark er en ideologisk legitimering af folkemord. Her er der i eminent grad tale om den tendens, Dort omtaler: "Hele western-filmens moderne udvikling ... priviligerer Historien på mytens bekostning« (p. 64).

\section{Spaghetti-westerns}

Man kan med rimelighed indvende, at en behandling af spaghettiwesterns ikke er på sin plads $\mathrm{i}$ denne sammenhæng. Det er jo kun det ene af mytens elementer - henvisningen til de eksistentielle livsvilkår der er aktuel for europæere. Det er ikke Europas historie, der genskrives $i$ beretningerne om det vilde vesten, men USA's. Europa har aldrig haft en frontier, og den europæiske selvforståelse er ikke bygget op på myten om en sådan. Det er da også tydeligt, at »heltene« i spaghetti-westerns henter "stof" andre steder fra end hos det vilde vestens nybyggere, f.eks. fra den europæiske bandit-tradition, hvor banditterne ikke opererer på en frontier til en ødemark, men på grænseområderne mellem forskellige feudale delstater, dér hvor denne magt ikke helt behersker det sociale liv, men stort set nøjes med at udplyndre den fattige befolkning.

Når jeg alligevel - på trods af disse indvendinger - kort vil omtale spaghetti-westerns, er del fordi de trods alt føjer sig ind i den sammenhæng, jeg her har skitseret. I Europa udvikles - omend en smule senere - den samme produktionsstruktur som i USA og dermed de fundamentalt samme livsbetingelser. Forbruget af westerns i Europa er af et sådant omfang, at ogsă europæiske tilskuere mă formodes i et vist omfang at kunne tolke sine erfaringer og problemer i genren, eftersom modsætningen mellem social realitet/umiddelbare erfaringer på den ene side og kapitalistisk ideologi på den anden side også findes i Europa, såvel som alle andre steder med udviklet kapitalistisk produktionsmåde. Har Europa ikke haft en frontier, så findes ikke desto mindre her mange af de samme ideologiske størrelser: individualisme, fremdrift, forestillinger om, at »enhver er sin egen lykkes smed «, osv.

Spaghetti-westerns opstår samtidig med sen-westerns og ligger på nogle punkter i forlængelse af denne tradition, men med en del afgørende forskelle, som jeg finder det vanskeligt helt at få hold på. I $L a$ Western karakteriseres genren på følgende måde: »Denne ødelæggende produktion (i Paris er to trediedele af de westerns, der spilles, italienske), som kun udmærker sig ved sin underlødighed og uærlighed ... (p. 332). Her beskrives genren som et totalt degenereret forfaldsfæno- 
men, et »nassefænomen« i forhold til den sande western: »For enhver som elsker western-filmen, den sande western-film, dens miljø, dens mytologi, dens myte og dens usammenlignelige forestillingskraft, kan der her kun være tale om forfalskede varer, som western-elskeren må være speciel mistroisk overfor « (ibid.).

Denne karakteristik finder jeg for enkel. Spaghetti-western-»heltenes« manglende »moral« er dog evident: Clint Eastwood, Lee van Clef og Charlie Bronson handler tydeligt nok ikke, som John Wayne, i nogen autentisk morals tjeneste. De er lige så korrupte som de kapitalister, de sætter sig op mod, drevet som de er af pengebegær og/eller ubearbejdet personlig og traumatisk hævntørst. Der er altså ikke tale om forsøg på at mediere nogle autentiske idealer i forhold til en fremmedgjort socialitet, men om konflikter mellem forskellige fraktioner inden for denne socialitet, hvor disse fraktioner er iklædt mytens forskellige $y d r e$ attributter, hhv. frontier-heltens og den korrupte bykapitalist.

I mine forsøg på at forklare dette fænomen vakler jeg hele tiden mellem to tendenser, som måske begge er rigtige, eller forkerte? 1) Spaghetti-westerns kan ses som et forsøg på - i forlængelse af sen-westerns - at "nedskrive« myten, vise dens realitet, vise at koloniseringen ikke var den kultivering af ødemarken, som den klassiske western og overwestern'en hævder, men at der fra starten var tale om grusomhed, undertrykkelse og pengebegær. Set i dette lys vil spaghetti-westerns være udtryk for en progressiv, ideologikritisk tendens. 2) Men hvad der generer ved denne forklaring er den æstetiske iscenesættelse af dette voldsunivers. Volden er ikke "socialt retfærdiggjort «, men meningsløs, socialt. Derimod tillægger den æstetiske iscenesættelse af volden - i hvert fald hos Sergio Leone - denne en astetisk begrundelse og retfærdiggørelse, der også, i »anden omgang «, får en art "bagvendt « social begrundelse gennem skildringen af den korruption, mheltens« vold retter sig mod. Der er tale om et lukket voldsunivers, hvor "heltens" vold henter en indirekte legitimation fra den ydre lighed med den klassiske westernhelt og dennes gestus - som her er rent yderlig og løsrevet - samt denne gestus', hos Sergio Leone, kolossalt smukke og rituelle iscenesættelse. I den forstand kan spaghetti-westerns måske betragtes som et wnassefænomen «.

Socialpsykologisk betragtet er der begrundelser nok for, at denne voldsfascination kan fungere $i$ forhold til et nutidigt publikum, der selv lever $\mathrm{i}$ et uigennemskueligt voldssamfund, hvis konflikter spaghettiwesterns ikke hjælper publikum til at tematisere, men fastholder i sin lukkede uigennemskuelighed. Set i dette perspektiv socialiserer voldsfascinationen til nihilisme. Den griber fat i tilskuerens allerede eksisterende desperation over og had til et hårdt og uigennemskueligt samfund og le- 
gitimerer astetisk det individuelle småborgerlige desperado-oprør, hvis radikale sociale form er fascismen.

\section{Udviklingen i John Fords westerns}

Hvis de teser, jeg har formuleret mht. sammenhængen mellem det 20. århundredes sociale udvikling og western-strukturen, har noget på sig, så må nogle af de samme tendenser, jeg har forsøgt at formulere for genren som helhed, også slå igennem i de enkelte western-instruktørers udvikling, for så vidt de overhovedet er interesserede i og følsomme over for livsvilkårene i det samfund, de lever i, og deres forestillingsverden ikke er stivnet på et tidligt tidspunkt, så de blot gentager sig selv.

Dermed har jeg ikke sagt, at den enkelte instruktørs udvikling i et og alt er identisk med genrens samlede udvikling. Men min hypotese er, at de forhold, der producerer genrens udvikling, også pă en eller anden måde må slå igennem i den enkelte instruktørs udvikling, for så vidt denne skaber westerns i hele det tidsrum, jeg her har beskrevet.

Den betydeligste instruktør, der har produceret westerns lige fra begyndelsen af den klassiske periode frem til sen-western-perioden, er uden tvivl John Ford. Jeg vil derfor prøve at undersøge, hvorvidt - og i givet fald hvordan - den samfundsmæssige udvikling sætter sig igennem i Fords artikulation af western-myten og specielt dennes grundelement, the frontier.

De westerns af John Ford, jeg vil beskæftige mig med, mere eller mindre grundigt, er: My Darling Clementine (1946), Fort Apache (1948), Rio Grande (1950). Two Rode Together (1961), The Man Who Shot Liberty Valance (1961) og Cheyenne Autumn (1964). ${ }^{25}$

En hypotese om udviklingen i Fords westerns kunne være, at denne udvikling restløst afspejler radikaliseringen af modsætningen mellem frontier-idealer og social virkelighed på filmens produktionstidspunkt. Denne hypotese holder imidlertid ikke for en nærmere undersøgelse. Udviklingen i Fords westerns forløber ikke så lineært, som hypotesens gyldighed ville forudsætte. For at gøre rede for denne udvikling vil jeg $\mathrm{i}$ stedet vende tilbage til tesen om western-genrens funktion som forsøg på ideologisk legitimering, forstået således: John Ford tror fuldt og fast på frontier-idealerne, men han kan ikke, uden at miste sin moralske og kunstneriske integritet, se bort fra denne morals modsæatning til virkeligheden. For at legitimere myten må han derfor stadig mere radikalt udforske dens gyldighed, både som historisk realitet samt dens adækvathed i forhold til publikums (og Fords) fundamentale livsbetingelser.

Sammenfattende lykkes det Ford i de fleste westerns at »redde« my- 
ten, omend han må ty til over-westernagtige artikulationer af myten (Rio Grande, The Man Who Shot Liberty Valance), mens to må siges at falde fra hinanden, dvs. løsningerne bliver, på Fords egne præmisser. skinlosninger eller åbenlyst selvmodsigende (hhv. Chevenne Autumn og Fort Apache). I Two Rode Together bryder myten på helt senwesternsk facon sammen og bliver tragisk, mens My Darling Clementine må karakteriseres om en art overgangsform mellem den klassiske western og over-westerns.

Lad os se lidt narmere på dette. I My Darling Clementine er byen som sådan, som begreb, mere positivt valoriseret end i f.eks. Diligencen. Hovedpersonen Wyatt Earp er i filmens start kvægdriver og -ejer, dvs. lever af at sælge kød til byerne, men driver selv kvæget langs the frontier, dvs. han er også, og forst og fremmest, en frontier-mand, hvis lov han representerer. Da Clanton-familien fra the OK Corral ved Tombstone stjæler hans kvæg og dræber hans broder, og da sheriffen $i$ Tombstone nedlægger sit hverv i frygt for at konfrontere Clanton-familien - her findes to negative by-elementer: 1) byen gor folk slappe og opportunistiske i forhold til det at kæmpe for retfærdigheden, 2) selve værdiakkumulationen fremmer berigelse uden naturlig produktion: tyveri af kvæg, samt kortspil og prostitution i byen - påtager Earp sig jobbet som sherif, for på én gang at udrense civilisationens onde elementer og få personlig hævn, - et almindeligt dobbeltmotiv i westerns: for frontier-individet er der, som nævnt tidligere, ikke forskel på individuel og social moral. Denne overgang fra frontier-individ til sherif foregår, markeret af barbering og parfumering (jvf. Wollen) bemærkelsesværdigt smertefrit. Gennem udrensningen af det onde, Clantons, lægges grunden til en sund civilisation: pigen Clementine vælger at blive $i$ Tombstone for at grundlægge en skole. Denne relativt ukomplicerede overgang er et træk fra den klassiske western, mens selve temaet, valget at påtage sig ansvaret for loven, samt Earps tovende fremfærd, usikre og langsomme totale integration peger frem mod óver-westerns vanskelige valgsituationer $o g$ smertefulde integration.

I Fort Apache udfordres integrationen frontier/civilisation forste gang hos Ford af det forhold, at han opdager, at indianerne ikke er vild natur, men civilisation med højt udviklede moralbegreber. Da yankee'erne svigter deres lofte til indianerne, tvinges disse til at kæmpe i et slag, hvor yankee-hæren massakreres. Ikke desto mindre, til trods for at hele filmen har vist det modsatte, slutter filmen med en hyldest til kavalleriet som den nye civilisations fortrop. Her anslås altså et tema, som senere (i Two Rode Together og Cheyenne Autumn) skal vende op og ned på mytens struktur hos Ford, men som her på ydre og rent deklamatorisk vis negeres. 
Rio Grande foregår på the frontier: udenfor på ødemarken findes faren, indianerne, indenfor, østpå den degenererede civilisation, der repræsenteres af oberst Cohills forfinede kone, der kommer for at hente sin søn tilbage til Boston. Cohill selv er en over-western-agtig frontierhelt »indhentet af alderen« (Dort), illusionsløs, delvist stivnet i rutine. Integrationen mellem frontier og civilisation finder sted, da indianerne bortfører nogle hvide børn. De befris, oberst Cohill vinder gennem sin dåd sin kone tilbage, da hun erkender frontier-livets autentiske værdier. Sønnen, der hidtil har stået i skyggen af sin fader, beviser sin mandighed, eller rettere, han udvikler den og bliver en mand. Selv om integrationen således finder sted, er selve artikulationen af problematikken delvist flyttet ind $i$ individerne: det galder ikke blot om at overvinde den ydre fare, ødemarken, indianerne, men også sig selv (selv om denne selvovervindelse slet ikke har den smertefulde karakter som hos f.eks. Hathaway).

Two Rode Together er uden tvivl Fords mest illusionsløse og desperate formulering af frontier-myten og dens relation til virkeligheden. I byen lever sherif McCabe højt på sin position: han får 10\% fra saloon'en $o g$ andre handlende for at beskytte dem. Her er lovinstitutionen helt blevet kapitaliseret, gjort til forretning, da han hentes af kavalleriet for at hjælpe det med at hente nogle hvide børn tilbage, som er blevet bortført af comancherne. Grunden til at det er ham, der skal bruges til dette job, er, at hæren har en fredsaftale med comancherne, samt at McCabe står på særlig god fod med indianerne, da han handler med dem, også med våben. Han går ind på jobbet (sammen med Jim Gary, der beordres til det) på betingelse af passende betaling.

Indianersamfundet er et organiseret samfund, splittet i to tendenser: én tendens der er villig til at handle og forhandle med de hvide, og en radikal fløj, der vil kæmpe med våben mod de hvide kolonisatorer. ${ }^{26}$ Presset fra den hvide civilisation har altså allerede splittet indianersamfundet, der er præget af de samme modsætninger og onder som de hvide bysamfund. Det lykkes at kobe to hvide tilbage, den ene mod sin vilje: han er blevet comanche efter at have levet som sådan siden sin tidligste barndom. Men det hjælper ikke, her gælder kun pengene og våbnene.

Da McCabe og Jim Gary vender tilbage med de »befriede«, viser den hvide civilisation hele sit barbari. Ingen vil vide af den »vilde« comanche-dreng, der spærres inde i et bur og vises frem som et dyr i zoo. Kun en kvinde, der er blevet sindforvirret af sorg over at have mistet sit barn, tror at genkende sin søn og får ham. Da hun løsner ham for at give ham noget at spise, myrder han hende for at slippe vak. Den hvide civilisations reaktion er lige så barbarisk: øjeblikkelig lynchning. I samme øjeblik, han bliver hængt, afsløres det, ved hjælp af en spilledåse han 
havde haft som lille, at det i virkeligheden er broderen til Jim Garys veninde. Men da er det for sent.

Her er western-myten totalt brudt sammen og skånselsløst destrueret. Såvel den hvide civilisation som indianersamfundet er blevet gennemkorrumperet af pengeøkonomien, alle sociale relationer er uigennemskuelige. det er umuligt at kende forskel på godt og ondt, et mytesammenbrud, der kun på det helt overfladiske narratologiske plan søges dæk ket af en derealisationsteknik: den sociale modsætning forskydes til sidst til en personlig, der hele tiden har været et bitema: McCabe făr den spanske kvinde, han købte fri af comancherne, og Jim Gary făr sin veninde. En »happy-end« som står i skrigende modsætning til det tragiske mytiske og moralske sammenbrud.

Jeg har et par gange tidligere været inde på frontier-moralens billedog montagexstetiske manifestationer. I Two Rode Together manifesteres det mytiske sammenbrud i en »nedskrivning« og udtynding af filmsproget. Her er ingen storslåede panoramaer eller differentieret syntagmatik. Hele den klassiske filmæstetik, som Ford udfolder så virtuost $i$ sine andre westerns, lige fra Diligencen, er her reduceret til nogle fă figurer, specielt scener (jvf. Metz). Det mytiske sammenbrud manifesteres i en opprioritering af dialogen og det mest dialog-egnede og actionfremmede syntagme, scenen.

Two Rode Together er uden tvivl Fords mest desperate udforskning af myten. I sine senere westerns, The Man Who Shot Liberty Valance vender han tilbage til bycivilisationen og temaet formaliseret lov vs. naturlig frontier-lov, en modsætning der manifesteres i symbolet kaktusrosen. I Cheyenne Autumn er det igen »ødemarksproblematikken«, der tages op. Men nu med en omvending af mytens poler: indianerne repræsenterer den naturlige sunde civilisation, de hvide den truende fare.

I The Man Who Shot Liberty Valance lykkes det at mediere modsætningen bycivilisation vs. frontier. Politikeren (dvs. det selvstændiggjorte samfunds repræsentant par exellence) uddriver tilsyneladende det onde af civilisationen i en revolverduel med banditten Liberty Valance. I virkeligheden er det frontier-manden, der, stående i skjul, skød ham. Men politikeren får æren og fører samfundet videre, mens frontier-helten. efter at have udrenset det onde og dermed lagt grunden for en sund civilisation. selv frivilligt går til grunde. Han var nødvendig, mens hans tid er forbi.

I Cheyenne Autumn er det som nævnt indianerne, der er positivt valoriseret, de hvide negativt. Medieringen. der består i at de hvide langt om længe holder deres ord over for indianerne, finder sted på ret utraditionel vis, via intervention fra indenrigsministeren i Washington (en traditionelt meget negativt valoriseret størrelse i westerns), der dog er en 
gammel mand og - anes det - med gamle frontier-erfaringer. Men under alle omstændigheder er det i sig selv udtryk for frontier-mytens krise og sammenbrud for denne, at Ford må ty til den intervenerende statsmagt, for at redde medieringen i land, selv om det sker via en gammel frontier-mand, der står i modsætning til resten af statsbureaukratiet.

Sammenfattende om John Fords udvikling: Jeg mener at have påvist, at de forhold, der determinerer genrens samlede udvikling, også slår igennem hos John Ford. Men den gør det ikke på en sådan måde, at der er tale om en liniær udvikling fra klassisk western til sen-western. Udviklingen er mere ujæun, formidlet som den er af Fords personlige kamp med myten og realiteten.

\section{Konklusion}

Følgende skema skal ses som et forsøg på at sammenfatte de karakteristiske træk i western-genrens udvikling:

1. Den klassiske western: medieringen lykkes gennem et episk forløb. Uproblematisk helt.

2. Over-western: medieringen lykkes gennem et romanagtigt forløb. problematisk helt.

3. Sen-western: medieringen mislykkes. Romanstruktur. Tragisk helt eller anti-helt.

4. Spaghetti-western: der forsøges ikke nogen mediering. Narratologisk sammenbrud. Stereotyp »helt« eller »ikke-helt «.

Det, jeg har gjort, er altså, at jeg har fremanalyseret nogle træk, der formodes at være typiske for forskellige westerns, produceret på et bestemt »tidspunkt«. Ved »tidspunkt« har jeg ikke forstået dato eller år, men tidsrum af større omfang, nærmere bestemt perioder, bestemt af kapitalens udvikling. Den periodicering, der er underforstået, er ikke den traditionelle krisecyklus, der normalt er af 5-10 års varighed, men forløb af den art, Mandel kalder »lange bølger«, og som er af 25-30 års varighed. Hver af disse lange bølger kan have positiv eller negativ "grundtone«, dvs. være karakteriseret af fundamental vækst eller fundamental stagnation, ud over de traditionelle krisecykler, de rummer. Men det er, som det vil fremgå, af underordnet eller slet ikke af betydning for western-mytens artikulation.

Den klassiske western udvikles under den lange bølge med »depressiv grundtone«, som, ifølge Mandel, strækker sig fra 1913 til 1940. Det er den fundamentalt kriseramte del af den traditionelle imperialisme, med stærkt synkende profitrate. 
Det er dog tilsyneladende ikke dette der er af betydning her. Vi har set, at den klassiske western - som produceres under en lang bølge med depressiv grundtone - har lettere ved at holde sammen på myte-universet end over-westerns og sen-westerns, der bliver til i en efterfølgende "lang bølge« med ekspanderende "grundtone«. Endvidere vil det være helt umuligt at påvise nogen sammenhæng mellem artikulationen af western-myten og de korte krisecykler.

For at forklare dette, vil jeg vende tilbage til en pointe hos Mandel, der er vigtig i denne sammenhæng. De »lange cykler « kan ikke forklares rent kapitallogisk, dvs. ud fra værdi- og akkumulationsbegreber alene, men må medreflektere produktionsmådens stoflige grundlag. En »lang bølge « med ekspansiv grundtone baseres på fremkomsten af ny teknologi og produktionsorganisering og efterfolges af en »lang bølge« med negativ grundtone, når denne teknologis muligheder for fortsat kapitalvalorisering er udtømt. Den klassiske imperialistiske produktionsstruktur er primært kendetegnet ved ulige bytte mellem de imperialistiske metropoler og de »underudviklede« lande. I de imperialistiske lande overlever en kraftig sektor med småborgerlig produktion samt en høj grad af håndværksmæssig produktion $\mathrm{i}$ industrien, eller $\mathrm{i}$ det mindste håndværkspræget arbejde.

Efter 2. Verdenskrig derimod, under sen-kapitalismen, skabes det økonomiske boom gennem den 3 . industrielle revolution, der radikalt ændrer individernes arbejdssituation og samlede livsvilkår. Den småborgerlige produktion reduceres voldsomt, millioner af småborgere bliver arbejdere, vedhæng til maskinerne $\mathrm{i}$ en gennemorganiseret og -rationaliseret arbejdsproces. Kapitalens udjovnende tendens slår igennem og underlægger sig stadig flere livsområder, proletariserer millioner og gør - via kravet om kæmpekapitaler - drømmen om en tilværelse som selvstændig til en illusion for masserne.

Der er derfor ikke noget mærkeligt $i$, at det er under en lang bølge med ekspansiv grundtone, at western-myten kommer i krise. Det er den kapitalistiske ekspansions stoflige grundlag efter 2. Verdenskrig, der udraderer mytens sociale grundlag. Dette afspejler sig i over-westerns samt i sen-westerns, hvor mytens krise radikaliseres. Ideologien er altså kommet $\mathrm{i}$ krise før økonomien kommer det, eftersom individernes livsbetingelser andres radikalt og på en måde, der stadig vanskeligere lader sig forene med nationens ideologi. Derfor er vi da også i nogle senwesterns - først og fremmest Peckinpah's - vidne til en tendens til (borgerlig) lonarbejderideologi: resigneret given afkald på at leve hele myten, resigneret forsøg på at overføre elementer af den så som »ærlighed«, »beskytterfunktion« o.l. på en loyalitet i forhold til arbejdsgiveren, en tendens der dog af Peckinpah entydigt beskrives som degradering. 
Jeg håber hermed at have påvist, eller i det mindste sandsynliggjort, at western-genrens udvikling følger en social »lovmæssighed «, at udviklingen er "nødvendiggjort" af ændrede livsbetingelser for publikum. Det betyder dog ikke, at et nutidigt publikum slet ikke kan »spejle« sig i og »bruge« en klassisk western som Diligencen. Ingen western vil nogen sinde blive helt uaktuel under kapitalismen, da den fundamentale modsætning mellem selvstændiggjort social udvikling og individcentreret ideologi altid vil være til stede og dermed ramme noget i publikums erfaringer, ligesom den klassiske westerns - for et moderne publikum nemme løsninger vil kunne nydes nostalgisk.

At denne mulighed for at bruge myten nostalgisk-kompenserende også er til stede, viser sig i mange dårlige westerns og western-komedier, der helt har opgivet at udfolde mytens problematik, dens problemkompleks, men - måske ikke ulig spaghetti-westerns - iscenesætter losrevne elementer af den til ren underholdning og kompensation, uden forsøg på reel mediering af reelle modsætninger. Hermed er vi ude $\mathrm{i}$ egentlige trivi-westerns, men de er ikke emnet for denne analyse, - for der er i realiteten ikke længere tale om westerns.

\section{Noter}

1. Sunset Boulevard nr. 5.

2. At Bazin ikke heri ser en nødvendig degenerering af genren, men ser genrens mulighed for »organisk « at indoptage nye problemstillinger i sin mytiske diskurs, er en af de ting. der gør Bazin til en så fremragende analytiker, som han er, og să meget større end de teorier. han ekspliciterer.

3. Udtrykket stammer fra Jürgen Habermas (1971) og betyder, at den pågældende kategori »lar seg ikke losrive fra det borgerlige samfunns saregne utviklingshistorie (s. XIIX).

4. Dette betyder ikke, at jeg vil afvise muligheden af at påvise strukturelle fællestræk me]lem western-myten og f.eks. antike myter eller indianermyter. Det jeg vil betvivle er, at det er sådanne eventuelle fællestræk, der er årsagen til western-genrens universalitet og masse-udbredelse. F.eks. taler de antike myter ikke uformidlet til et massepublikum i dag, hvilket jo ikke betyder, at de ikke kan hringes til at tale.

Jeg vil ikke foregive at give en almen løsning på historicitetsproblemet. Mit ærinde er at forsøge at forklare western-filmens universalitet og dens udviklingslogik. I dette forsøg er jeg styret af en opfattelse af kunstens historicitet, der ligger nær ved den af Arnold Hauser formulerede: "Hvis formălet med historieforskningen er at forstå nutiden - og hvad kunne det ellers være? - så nærmer denne undersøgelse sig sit mål. Det er den moderne kapitalisme, det moderne borgerlige samfund, den moderne naturalistiske kunst og litteratur, kort sagt hele vores egen verden, som vi nu skal beskæftige os med. Vi stăr over for nye forhold, nye livsformer og føler det, som om vi er afskăret fra fortiden. Men på intet andet område er indsnittet vel så dybt som i litteraturen, hvor grænsen mellem de ældre værker, som kun er af historisk interesse for os, og de værker, som skabes fra dette tidspunkt og fremefter, og som endnu i dag er mere eller mindre aktuelle, repræ- 
senterer det mest følelige brud, som vi kender i kunsthistorien. Det er først værkerne på denne side af grænsen, der udgør den modeme, levende litteratur, som direkte beskæftiger sig med vore egne livsproblemer. Vi er adskilt fra de ældre værker af en afgrund, der ikke kan bygges bro over - at forstå dem kræver en særlig indstilling, en særlig anstrengelse, og tolkningen af dem er for os altid forbundet med faren for misforståelser og forfalskninger. Vi læser den ældre litteraturs værker på en anden måde end vor egen tids; vi nyder dem på en rent æstetisk måde, det vil sige indirekte, uden at være involveret, idet vi er os det fiktive ved dem og vort eget selvbedrag fuldstændig bevidst. Dette forudsætter synspunkter og evner, som gennemsnitslæseren på ingen måde råder over; men selv den historisk og æstetisk interesserede læser føler, der er en umådelig forskel mellem varker, som ikke har nogen umiddelbar forbindelse med hans egen tid, hans egen livsfolclse og măl i tilværelsen, og sảdanne værker, som er vokset frem af selve denne livsfølelse og søger et svar på spørgsmålet: hvordan kan man, hvordan bør man leve $\mathrm{i}$ denne vor nutid? « (Hauser. 1980, bd. 11, pp. 231-232).

5. Som det vil fremgå af det følgende er problemet om westem-mytens klassekarakter et ret kompliceret spørgsmål.

6. Frederick Jack Tumer: The Frontier in American History. New York, 1920. Her og $\mathrm{i}$ det følgende citeret fra uddragene i Göran Rystad: Amerika. Stockholm, 1969.

7. Det drejer sig bl.a. om Benjamin F. Wright i Institutions and the Frontier og Richard Hofstadter: Turner and the Frontier Myth. Uddrag af begge i Rvstad.

8. Begrebet »afspejling « er hentet fra den marxistiske bevidsthedsteori og æstetik. Der er tale om et begreb, der ikke altid bruges lige stringent. Men jeg vil ikke i denne sammenhæng søge at afklare det. Her skal det blot bruges til at sige, at der er en sammenhang mellem de samfundsmæssige problemstillinger på filmens produktionstidspunkt og genrens udvikling, samt at denne sammenhæng har karakter af et årsagsforhold gående fra materialhistorien til filmen. Ordet har i denne sammenhæng ingen nedsættende konnotationer, ligesom dette heller ikke er tilfældet med begrebet ideologisk legitimering. hvilket gerne skulle fremgă af min analyse af udviklingen i John Fords westerns. Disse westerns kan, i den vage betydning som jeg her bruger begreberne $i$, siges at afspejle det 20. århundredes (især amerikanske) historie, ligesom de kan siges at være styret af et mlegitimeringsonske«. Mere om dette i analysen.

9. I Diligencen. som i mange andre klassiske westerns, er indianerne en del af naturen, dvs. de betragtes ikke som en kultur. At dette ikke er en fast del af det Ford'ske myteunivers, vil fremgå af det folgende.

10. I Christian Metz' stursyntagmatiske terminologi er der tale om et klammesyntagme (syntagme en accolade).

11. Termen wsekvenser« er her anvendt $i$ den løsest mulige betydning som stort set synonym med »forløb«.

12. Det er tale om folgende fire »sekvenser«:

a) Gatewood forskrakkes, da han hører, at Geronimo er på krigsstien og klager over, at passagererne ikke er blevet advaret. Men samtidig kan han ikke indromme sin uvidenhed uden at afsløre sine egne planer om at stikke af med bankens penge. Efter denne samtale, hvis indhold er den ydre trussel fra Geronimo (i ødemarken) kontrastklippes til landskabet: "Diligencen og kavalleritroppen ses nu i totalbillede, mens de bevæger sig hen over prærien og ses som silhuetter mod aftenhimlen. . a (Ford \& Nichols, p. 53). b) Curley siger til Buck: »Telegrafen virker ikke«, og refererer dermed ti! det truende indhold $\mathrm{i}$ samtalen $\mathrm{i}$ a). Derefter klip: $\gg \mathrm{Nu}$ ses en del af prærien $\mathrm{i}$ halvtotal og total. . « (ibid. p. 53-54). c) Ringo fortæller om sin broder og siger: "Han blev myrdet:/klip til nærbillede af de andre passagerers reaktion/k/ip: »Nu ses diligencen $\mathrm{i}$ halvtotal og total mens den kommer hen imod kameraet. . . (ibid. p. 57). d) Der er ved at opstå konflikter i diligencen meliem Doc Boone og Hatfield, hvor Doc indirekte insinuerer, at Hatfield kan finde på at skyde folk i ryggen/klip: »Diligencen og de eskorterende kavallerister ses fra en meget høj vinkel, mens de bevæger sig sporet i Monument Valley. . « (ibid. p. 58).

13. Individets samfundsmæssige bevidsthed og adfærd, for să vidt denne er bestemt af individets sociale placering.

14. Denne konflikt er hovedtemaet i et par westerns af Howard Hawks, Rio Bravo fra 1958 
og El Dorado fra 1967, hvor sheriffen ødelægges menneskeligt af netop denne modsætning, og hvor det først er tilstedeværelsen af og alliancen med frontier-helten og hans enkle og naturlige moral, der giver sherif-institutionen dens sundhed tilbage.

15. Diligencen adskiller sig ikke să radikalt fra mytens grundstruktur, som Peter Larsen postulerer. Den væsentligste anormalitet er, at det ikke lykkes at integrere bankmanden Gatewood til sidst. Men her er der - som påvist af Larsen - tale om et konjunkturpolitisk specifikt forhold: tilslutningen til New Deal. Men det må understreges, at det specifikke her ikke ligger i, at Gatewood er en tvivlsom person, men i at det ikke trods alt lykkes at integrere ham.

16. Dette rokker ikke på nogen mâde ved den her formulerede hovedtese. Jeg har på intet sted postuleret et automatisk afspejlingsforhold, men kun tendenser, der »med nødvendighed» sætter sig igennem som tendenser, som dominerende strømninger, for at myten skal kunne overleve og bevare sin brugsværdi. Men det forhindrer selvfølgelig ikke Hawks $i$ at beslutte, at nu vil han ganske anakronistisk vælge at lave en klassisk westem i 1967. Filmen har da også tydelige nostalgiske undertoner.

17. Citeret efter hukommelsen fra en synkroniseret version vist $i$ tysk $T V$.

18. Angiver i Freuds drømmetydning det forhold at flere forskellige forestillinger smelter sammen i et enkelt symbol.

19. Man kan selvfølgelig diskutere, om rodeo-film kan regnes med til western-genren. Philip French afviser dette. Men jeg anser problematikken i Junior Bonner for at være en radikalisering af den, der findes i De red efter guld (og Peckinpahs øvrige westerns).

20. Ligesom tilfældet var mht. over-westerns, er også mit analysemateriale af sen-westerns begraenset.

21. Dette tema uddyber Peckinpah i Junior Bonner.

22. Jeg kalder her. og i det følgende, personeme ved skuespillernes navne, da jeg har glemt, hvad de hedder i filmen.

23. Dette tema med pigen, der under falske forudsætninger er blevet gift med en af guldgraverne, og derfor først egent lig er moralsk fri i det øjeblik, hendes mand har dræbt hendes fader, kunne nok fortjene en grundigere behandling. Familien og ægteskabet som institution er en væsentlig del af westem-myten, en del af grundlaget for den småborgerlige produktion, bosættelsen ved the frontier og opbygningen af et nyt samfund.

24. Konkret hæudes filmen at være inspireret af My Lai-massakren $i$ Vietnam.

25. Dette udvalg er temmelig tilfældigt, for sấ vidt der er tale om de film, jeg husker bedst. Det forhold, at jeg ikke kender alle Fords westerns lige godt, og at der er nogle få, jeg aldrig har set, udgør naturligvis en alvorlig mulig fejlkilde, som jeg her onsker at påpege.

26. Der er her tydeligt nok tale om en modsetning, der henter sit indhold i den splittelse, der i begyndelsen af 60'erne var ved at opstå blandt de sorte i USA mellem Martin Luther Kings borgerretsbevægelse og en radikal Black Power.

\section{Litteratur}

Andersen, Lissi Ørvad m.fl: Tegneserier. En ekspansions historie, Grenaa, 1973.

Bächlin, Peter: Der Film als Ware, Frankfurt am Main, 1975.

Bazin, André: Qu'est-ce que le cinéma? I, Paris, 1958. Heri: L'Evolution du langage cinématographique. På dansk: Filmsprogets Udvikling, in: Se - det er film, bd. 1., København, 1964.

Bazin, André: Qu'est-ce que la cinéma? III, Paris, 1961. Heri a) Le western ou le cinéma américain par excellence, b) Evolution du western. På dansk: a) Western-filmen eller amerikansk filmkunst par excellence, b) Western-filmens udvikling, in: Se-det er film. bd. II, København, 1965.

Dort, Bernard: La nostalgie de l'épopée, in: Le Western.

Ford, John \& Dudley Nichols: Stagecoach, London, 1971.

French, Philip: Westerns. Aspects of a Movie Genre, London, 1973. 
Glucksmann, André: Le's aventures de la tragédie, in: Le Western.

Goldmann. Lucien: Pour une sociologie du roman. Paris, 1964.

Habermas, Jürgen: Borgerlig offentighet, Oslo, 1971.

Hauser, Amold: Kunstens og litteraturens socialhistorie. bd. II., Kobenhavn, 1980.

Hesselberg, Claus: Westerns, in: Sunset Boulevard nr. 5.

Holzer, Horst: Massekummunikation som vidensformidling, socialterapi og legitimationshjalp. in: Mediesociologi, Kobenhavn, 1974.

Kaarsholm, Preben: Oprorets dialektik, in: Filmanalyser. Viborg, 1974.

Larsen. Peter: Simähorgeren i kamp. in: Filmanalyser. Viborg, 1974.

Mandel, Ernest: Senkapialismen /-2. Stockholm, 1974.

Metz, Christian: Essais sur la signification aucinéma I, Paris, 1968.

Mitry, Jean: John Ford. Paris, 1954.

Rystad, Göran (ed): Amerika 1, Lund, 1972.

Sunset Boulevard nr. 5. Specialnummer om westerns.

Turner, Frederick Jackson: Gränslandets betvdelse i amerikansk historia, in Rystad.

Le Hestern (ed. Raymond Bellour), Paris, 1966.

Wollen, Peter: Signs and Meaning in the Cinema, London. 1969. 